\title{
PRISEGE I NAPUTAK - PRAVNI OKVIR ZA DJELOVANJE MLETAČKOG KNEZA NA ČELU SREDNJOVJEKOVNOG DUBROVNIKA*
}

\begin{abstract}
U radu se raščlanjuju dvije prisege i naputak, pravni izvori koji su uređivali djelovanje mletačkog kneza na čelu srednjovjekovnog Dubrovnika. Posebno se detaljno analizira i u prilogu objavljuje dosada u hrvatskoj historiografiji neobrađivani tekst kneževe prisege duždu, koji vrvi obavijestima o mletačkoj upravi nad Dubrovnikom u 13. i prvoj polovici 14. stoljeća. Utvrđuju se veze između spomenutih vrela i njihovo značenje za dubrovački pravni poredak te ispituje njihova povezanost $\mathrm{s}$ tada popularnom literaturom o odlikama "dobre vlade".

Ključne riječi: Dubrovnik; Mletačka Republika; srednji vijek; knez; uprava; prisega; naputak.
\end{abstract}

Budući da je u 13. i 14. stoljeću mletačka vlast prema novostečenim posjedima vodila pragmatičnu politiku s polazištem $u$ zatečenome stanju, ${ }^{1}$ ovlasti poglavarâ na njihovu čelu nisu bile jedinstvene već definirane čimbenicima koji su se razlikovali od sredine do sredine.

Ta se raznolikost može ocrtati kratkom usporedbom upravnih modela u Zadru i Dubrovniku na koje se mletačka vlast protegnula početkom 13. stoljeća. Zadar je pod mletačku vlast došao osvajanjem, a odmah po pacifikaciji grada sklopljen je sporazum (pactum) koji je uređivao odnose s Venecijom; ${ }^{2}$ dužnosti mletačkog kneza u institucionalnom okviru redovite uprave već su tada defi-

\footnotetext{
Ovaj je rad sufinancirala Hrvatska zaklada za znanost projektom broj 5106.
}

1 Ermanno ORLANDO, Politica del diritto, amministrazione, giustizia. Venezia e la Dalmazia nel basso medioevo, u: Venezia e Dalmazia (ur. Uwe Israel i Oliver Jens Schmitt), Roma: Viella, 2013., 14; Alessandra RIZZI, „Committimus tibi [...] quod de nostro mandato vadas”: le 'commissioni' ai rettori veneziani in Istria e Dalmazia. Nota introduttiva, $\mathrm{u}$ : Le commissioni ducali ai rettori d'Istria e Dalmazia (1289-1361) (prir. Alessandra Rizzi), Roma: Viella, 2015., 7.

2 Listine o odnošajih između južnoga slavenstva i Mletačke Republike, sv. I (prir. Sime Ljubić), Monumenta spectantia historiam Slavorum Meridionalium, sv. I, Zagreb: JAZU, 1868., br. 30, str. 21-22; Codex diplomaticus Regni Croatiae, Dalmatiae et Slavoniae, sv. III (prir. Tadija Smičiklas), Zagreb: JAZU, 1905., 45-47. 
nirane tekstom prisege duždu. ${ }^{3}$ Dubrovnik je pak podvrgnut mirnim putem, vjerojatno nakon unutarnjeg prevrata ${ }^{4}, \mathrm{i}$ prvih je tridesetak godina na čelu imao mletačke plemiće koji su kneževsku funkciju uzimali u svojevrsni zakup. ${ }^{5}$ Prvi sporazum (pactum) koji je uređivao odnose Dubrovnika s Venecijom donesen je tek 1232., ${ }^{6}$ a 1237. uveden je novi model izravne uprave (regimen), koju prati kneževa prisega komuni. ${ }^{7}$ Nadalje, tekst prisege zadarskoga kneza znatnije se mijenjao zbog pobuna i institucionalnih mjera koje su se nakon njih nametale, ${ }^{8}$ dok se u „mirnijem” Dubrovniku osnovni tekst samo nadopunjavao.

Zbog raznolikosti upravnih modela na područjima pod vrhovnom vlasti Venecije - koja je upravo ilustrirana na primjeru Zadra i Dubrovnika - mletačkog se plemića, izabranog za poglavara nekoga grada (kneza, načelnika, itd.), ${ }^{9}$ svaki put ispočetka moralo upoznavati sa specifičnim ovlastima i sadržajem službe. Prije odlaska na dužnost knez je polagao prisegu duždu, koja nije bila samo iskaz lojalnosti već i prilika za upoznavanje pravnog okvira nove funkcije.

Zadarski primjeri iz 13. stoljeća pokazuju da se pri polaganju prisege duždu rabio pisani tekst, ${ }^{10}$ izrađen u obliku pergamentske listine (iuramentum). ${ }^{11}$ Prema sadržaju podijeljenom na glave' isti se izvor ponekad nazivao i capitulare. ${ }^{12}$

3 Listine I, br. 31, str. 22-23.

4 Nenad VEKARIĆ, Nevidliive pukotine: Dubrovački vlasteoski klanovi, Zagreb - Dubrovnik: Zavod za povijesne znanosti HAZU u Dubrovniku, 2009., 29-30; idem, Vlastela grada Dubrovnika, sv. I - Korijeni, struktura i razvoj dubrovačkog plemstva, Zagreb - Dubrovnik: Zavod za povijesne znanosti HAZU u Dubrovniku, 2011., 213.

5 Nella LONZA, Mletačka vlast nad Dubrovnikom u ranom 13. stoljeću i „zakupno kneštvo” Giovannija Dandola (oko 1209-1235), Anali Zavoda za povijesne znanosti HAZU u Dubrovniku, 56, 2018., u tisku.

Listine I, br. 75, str. 46-49.

7 Vidi niže u tekstu.

8 Usporedi npr. prisege/naputke iz 1204./1205. (Listine I, br. 31, str. 22-23); 1243. (Listine I, br. 88, str. 61-63), 1248. (Listine I, br. 97, str. 74-76), 1278. (Listine I, br. 66, str. 116-118, ponovno iz originala u: Tomislav POPIĆ, Srednjovjekovni zadarski kapitulari, Povijesni prilozi, 42, 2012., 76-79); s kraja 1314. ili 1315. (Le commissioni ducali ai rettori d'Istria e Dalmazia (1289-1361) (prir. Alessandra Rizzi), Roma: Viella, 2015., 225; za dataciju vidi Listine I, 278, 287).

9 U nastavku uvodnog dijela rabim izraz “,nez”, bez obzira na to što su dužnosnici na čelu nekih gradova imali drugačiju titulu.

10 Npr. iuramentum comitis Iadre iz 1248. na kraju nosi bilješku „supra hoc capitulare iuravit vir Stephanus Justinianus comes Jadre" (Listine I, br. 97, str. 74-76).

11 U fondu Knjižnice sv. Marka u Veneciji (Biblioteca Marciana) čuva se prisega, odnosno kapitular za zadarskog kneza sastavljen 1278. (Capitulare comitis Jadre); za podatke o izdanju vidi bilj. 8.

12 Capitulare u najširem smislu označava svaki pravni propis podijeljen na glave (usp. Lexicon latinitatis medii aevi Iugoslaviae, sv. I (ur. Marko Kostrenčić), Zagreb: JAZU, 1969., 172). U mletačkoj pravnoj tradiciji koristio se već kao naziv za pravnu zbirku u formi duždevske prisege (promissio) Enrica Dandola iz 1192., a kasnije najčešće za zbirku organskih propisa vezanih uz rad neke insti- 
Novoizabranome se knezu predavala i druga isprava ad personam, nazvana naputak (commissio). ${ }^{13}$ Pojava pisanih prisega već početkom 13. stoljeća ${ }^{14}$ može se objasniti praktičnim razlozima fiksiranja sadržaja "crno na bijelo", ali i općenitom sklonošću mletačkih institucija prema pisanim pravnim instrumentima. ${ }^{15}$ U literaturi još nije riješeno opće pitanje je li se naputak kao pravni izvor javio kasnije od prisege ${ }^{16}$ i je li ju možda zamijenio i potisnuo ${ }^{17}$ ili je riječ o prividu zbog neravnomjerne očuvanosti najstarijih dokumenata.

Tijekom 13. stoljeća tekstove prisega/naputaka počelo se s pergamentskih listina prepisivati u opći registar za važne javnopravne akte da spretnije posluže kao obrazac u novoj prigodi. ${ }^{18}$ Međutim, kako je taj materijal postajao sve bogatiji, već je negdje između 1293. i 1297. uveden zasebni registar za prisege duždu i naputke vezane uz službe u Dogadu (na užem području oko Venecije, od Grada do Cavarzere) te $u$ Istri i Dalmaciji. ${ }^{19}$ Taj specijalizirani registar nastao je u vrijeme kada se duždevska kancelarija općenito dinamično razvijala i pokretala nove vrste upisnika. ${ }^{20}$ Iz osnovnog se teksta obrazaca s vremenom ponešto ukidalo ili mijenjalo, a sve do 1361. dodavane su nove glave s relevantnim odlukama najviših mletačkih institucija - Velikog vijeća, Senata, Vijeća četrdesetorice i Malog vijeća. Radi štednje prostora i truda prepisivača, dodaci nisu u svaki obrazac unošeni integralno već se samo na prvome mjestu prepisivao cijeli tekst, a u sve

tucije. Giorgio ZORDAN, Ordinamento giuridico veneziano, Padova: Cleup, 2. izdanje, 1984., 187, 203-205; za Zadar vidi POPIĆ, Srednjovjekovni zadarski kapitulari, 43-80.

U mletačkom je arhivu sačuvana isprava s prisegom zadarskog kneza Leonarda Querinija iz 1243., objavljena u Listine I, br. 88, str. 61-63.

RIZZI, „Committimus”, 14.

ORLANDO, Politica del diritto, 13-14.

RIZZI, „Committimus”, 8, 15. commissioni ducali, 64 .

Zbog znatne zastupljenosti dokumenata o sporazumima Venecije s drugim gradovima, ti su svesci u mletačkoj kancelariji dobili naziv Libri pactorum, a prvi je uspostavljen krajem 12. stoljeća. O toj seriji vidi Marco POZZA, I Libri Pactorum del comune di Venezia, u: Comuni e memoria storica. Alle origini del comune di Genova, Genova: Società Ligure di Storia Patria, 2002., 195-212. Na temelju prijepisa iz tih registara, Ljubić je objavio tekstove prisega zadarskog kneza iz 1204./5. i 1248. (bilj. 8).

19 Archivio di Stato di Venezia, Collegio, Formulari di commissioni, reg. 1. Dio tekstova koji se odnose na istarske gradove objavio je Bernardo BENUSSI, Commissioni dei Dogi ai Podesta veneti nell'Istria, Atti e memorie della Società istriana di archeologia e storia patria, 3, 1-2, 1887., 3-110, a svi dijelovi koji se odnose na Dalmaciju i Istru objavljeni su u: Le commissioni ducali ai rettori d'Istria e Dalmazia (1289-1361) (prir. Alessandra Rizzi), Roma: Viella, 2015. O nastanku spomenute zbirke, dataciji i tipologiji akata detaljno u RIZZI, „Committimus", 7-28. 
druge prisege ubačeni su znakovi koji na njega upućuju. ${ }^{21}$ Izradom tog registra završen je ustvari proces pretvorbe prisega duždu i naputaka kao konkretnih, pojedinačnih akata u opći i apstraktni normativni materijal.

Dosada je bilo riječi o prisezi i naputku koji su regulirali odnos novoizabranoga kneza prema duždu, odnosno središnjim mletačkim institucijama. Obveze kneza prema lokalnoj zajednici uređene su pak drugom prisegom, koja se polagala pri obredu preuzimanja službe $u$ tom gradu. Zbog sadržajnih i stilskih sličnosti s prisegom duždu, može se pretpostaviti da je njezin predložak bio pripremljen u Veneciji, a zatim se - kako pokazuju dubrovački primjeri - u lokalnoj kancelariji izrađivala isprava za svakog novog kneza. Knez je prisezao na Sveto pismo, no iz kasnijih se primjera vidi da je u tome obredu također polagao ruku na tekst prisege (vidi niže). Taj element, uz stilizaciju u prezentu, ukazuje na to da tekst prisege komuni nije bio tek naknadni pisani trag već održanog javnog rituala već da se pripremao unaprijed i imao ulogu u samome obredu. ${ }^{22}$

$\mathrm{U}$ ovom se radu razmatraju osnovni pravni izvori koji reguliraju djelovanje mletačkog kneza u Dubrovniku: kneževa prisega duždu i s njome povezani naputak te kneževa prisega komuni. Fokus je na razdoblju prije donošenja Statuta iz 1272., no, radi cjelovite obrade tih izvora, analizirani su i njihovi kasniji dodaci.

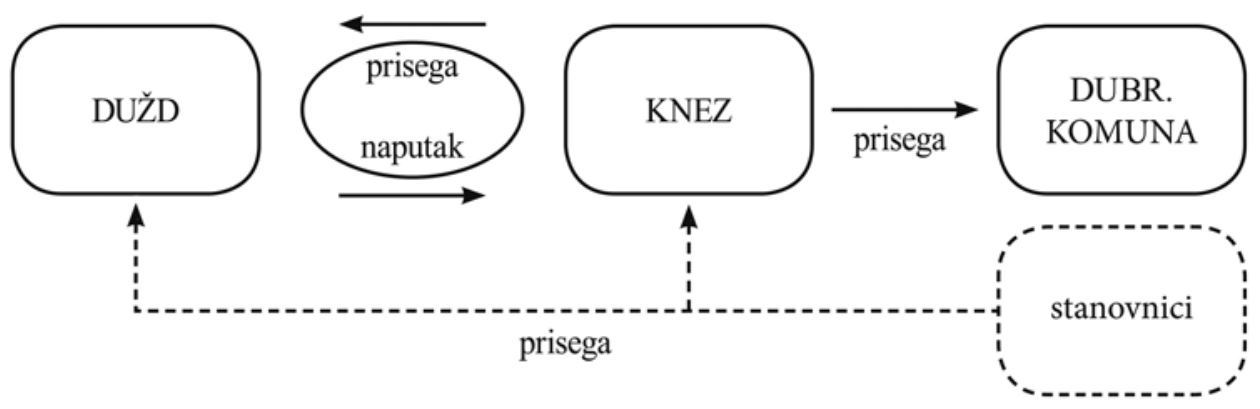

Slika 1. Skica odnosa dviju prisega i naputka dubrovačkog kneza

21 Gloria ZUCCARELLO, Il sistema delle aggiunte, u: Le commissioni ducali, 66-75.

22 U slučaju kneza Stefana Giustiniana prošlo je oko mjesec i pol od njegova dolaska u Dubrovnik do polaganja prisege. Državni arhiv u Dubrovniku, ser. 76, Diplomata et acta saec. XIII, br. 74. U izdanju u Codex diplomaticus Regni Croatiae, Dalmatiae et Slavoniae, sv. IV (prir. Tadija Smičiklas), Zagreb: JAZU, 1906., br. 108, str. 119, ispušten je odgovarajući dio teksta. 


\section{Prisega dubrovačkog kneza duždu prije odlaska na dužnost}

Među obrascima prisega duždu i naputaka koji su potkraj 13. stoljeća prepisani u jedinstveni registar, nalazi se i prisega dubrovačkog kneza duždu (vidi prilog). Kao što je i inače čest slučaj kod srednjovjekovnih pravnih izvora, ${ }^{23}$ pri prijepisu su već integrirane starije izmjene i dopune prisege, pa tekst djeluje monolitno, iako je ustvari plod dugotrajne sedimentacije. Premda najstarije preobrazbe nisu vidljive na prvi pogled i ne može se sa sigurnošću izlučiti prvotna tekstualna jezgra prisege, postoje tragovi koji omogućuju barem približnu dataciju izvornog teksta i nekih dodataka.

Kod prisege dubrovačkog kneza duždu prva je ruka krajem 13. stoljeća unijela $u$ registar prvih dvadeset glava. Budući da se spominje ugovor između Dubrovnika i Venecije, tekst je morao biti sročen nakon 1232. godine, kada je donesen prvi od tri takva ugovora. S druge strane, ne spominje se Statut iz 1272. već starija kaznenopravna zbirka iz vremena kneza Giovannija Tiepola (u službi 1237. - 1238.), što znači da je jezgra prisege očito sastavljena između 1237. i 1272.

U glavi o kneževoj družini spominju se dva kneževa pomoćnika. ${ }^{24}$ Dubrovački je knez u početku imao jednog pomoćnika, a drugi je uveden odlukom mletačkog Velikog vijeća tek 1256., ${ }^{25}$ što znači ili da je tekst sastavljen tek nakon toga ili da je naknadno mijenjan. Propis Vijeća iz iste godine kojime se proširuje zabrana primanja darova unesen je pak u prisegu dubrovačkog kneza u skraćenom obliku i očita je interpolacija u osnovni tekst. ${ }^{26}$

Analiza nekih prisega/naputaka iz istoga registra ukazala je na to da je njihova izrada $\mathrm{u}$ stopu pratila sporazume tih gradova s Venecijom. ${ }^{27}$ To bi moglo vrijediti i za Dubrovnik, ako su spomenute odredbe iz 1256. doista naknadni dodaci, interpolirani pri prijepisu u registar potkraj 13. stoljeća. U tom bi slučaju jezgra prisege duždu / naputka mogla biti s kraja 1230-ih, odnosno približno iz vremena kada je uobličen i tekst prisege kneza dubrovačkoj komuni, koja je po mnogočemu komplementarni pravni izvor. No, za tu logičnu pretpostavku zasada ne postoje čvrsti dokazi.

\footnotetext{
23 Primjerice, za Dubrovački statut vidi Nella LONZA, Dubrovački statut, temeljna sastavnica pravnog poretka i biljeg političkog identiteta, u: Statut grada Dubrovnika sastavljen godine 1272., Dubrovnik: Državni arhiv, 2002., 17-19, 21-23. Listine I, br. 112, str. 87; Deliberazioni del Maggior Consiglio di Venezia, sv. II (prir. Roberto Cessi) Bologna: Nicola Zanichelli, 1931., 336.

26 Prisega duždu, [16]; Usporedi Deliberazioni II, 334 i dulji izvod u prisezi zadarskog kneza u: Le commissioni ducali, 227.

27
} 
Premda je prvorazredan izvor za pravni položaj Dubrovnika pod vrhovnom vlasti Venecije, tekst prisege dubrovačkog kneza duždu promaknuo je pozornosti hrvatske historiografije, ${ }^{28}$ tako da je njegov sadržaj potrebno detaljnije razmotriti. $^{29}$

Knez se prisegom obvezivao da će u svojoj službi ostati dvije godine i da se za to vrijeme neće udaljavati iz Dubrovnika bez dopuštenja dužda i njegova vijeća (Malo vijeće). ${ }^{30}$ Sačuvani su primjeri takvih dozvola, naprimjer iz travnja 1274. knezu Nicoli Queriniju, a iz srpnja iste godine novom knezu Pietru Tiepolu. ${ }^{31}$ Da bi se osigurao nužni kontinuitet uprave, 1305. je propisano i dodano tekstu prisege da knez ne smije napustiti službu dok mu ne dođe nasljednik. ${ }^{32}$

Naknadno je unesena odredba o protokolu primopredaje stvari i novca nasljedniku u kneževskoj službi i obvezi sastavljanja izvješća o tome, ${ }^{33}$ a 1319. ona o predaji oružja. ${ }^{34}$ Time je ustvari uspostavljena procedura administrativne primopredaje dužnosti između starog i novog kneza.

Tek je 1338. regulirano vrlo važno pitanje predaje svih spisa koje je vodio notar dubrovačkog kneza u komunalnu kancelariju ${ }^{35}$ Nažalost, to je glavni uzrok što je za prvih stotinjak godina mletačke vlasti nad Dubrovnikom sačuvano uglavnom gradivo nastalo produkcijom komunalnog notara, a vrlo malo izvora o djelovanju predstavnika mletačke vlasti.

Knez se prisegom obvezivao da će na vlastiti trošak povesti petnaesteročlanu družinu (familia): dva pomoćnika Mlečanina (socii) s plaćom od barem 50 denara godišnje, kojima je morao nabaviti primjereno ruho, ${ }^{36}$ notara (klerika ili laika) i 12 slugu (servientes), od kojih 8 naoružanih, te 3 konja. Da bi se izbjegle sumnje u lojalnost, sluge nisu smjele biti iz Dalmacije. ${ }^{37}$ Članovima družine ka-

Ljubić je za svoje Listine crpio podatke iz najvažnijih serija Mletačkog arhiva, pa se olako uzimalo da je time iscrpljen materijal za dalmatinske gradove pod mletačkom vlašću u 13. i 14. stoljeću.

Skakanje s teme na temu u originalu posljedica je dodavanja novih stavki dopisivanjem ili interpoliranjem. Analiza stoga ne prati originalni slijed glava već se zasniva na tematskim cjelinama.

Prisega duždu, [2].

Listine I, br. 148, str. 107; br. 151, str. 108.

Listine I, br. 326, str. 211; Prisega duždu, [32].

Prisega duždu, [30].

Prisega duždu, [33].

Prisega duždu, [40]; Listine o odnošajih između južnoga slavenstva i Mletačke Republike, sv. II (prir. Sime Ljubić), Monumenta spectantia historiam Slavorum Meridionalim, sv. II, Zagreb: JAZU, 1870., br. 47 , str. 30 .

O njihovim nadležnostima vidi prisegu u Statutu II, 2. Liber statutorum civitatis Ragusii (prir. Konstantin Jireček i Baltazar Bogišić), Monumenta historico-juridica Slavorum Meridionalium, sv. IX, Zagreb: JAZU, 1904.; dalje: Dubrovački statut, uz broj knjige i glave.

Prisega duždu, [5]. 
snije je (možda između 1342. i 1350.) zabranjeno u sljedeće dvije godine otići u službu u istome gradu, da se pomoćno osoblje u toj sredini ne bi udomaćivalo i gubilo osjećaj lojalnosti prema mletačkim vlastima. ${ }^{38}$

Knez je obećavao da će u roku od petnaest dana nakon povratka u Veneciju stupiti pred dužda i njegovo vijeće i iznijeti sva saznanja o Dubrovniku koja mu se budu činila korisnim za mletačke interese i održanje tog područja. ${ }^{39}$ Nažalost, za izvješća kneževa podnesena nakon službe - koja su potencijalno izvanredan izvor informacija o lokalnim prilikama - tek se u 16. stoljeću počeo tražiti pisani oblik. ${ }^{40}$

U prisezi duždu sačuvan je trag financijske kontrole nad kneževima koji su se vratili s dužnosti. Kao što se čita iz motivacije odredbe, mletačke su vlasti pokušale njome stati na kraj financijskoj nedisciplini poglavara podložnih gradova, koji su se opravdavali da su neki troškovi „uobičajeni” i da su te izdatke imali i njihovi prethodnici. Stoga je, vjerojatno početkom 14. stoljeća, ta zabrana dodana svim obrascima prisega/naputaka, pa tako i onome za dubrovačkog kneza. Iz te se glave razabire i da su kneževi po povratku sa službe polagali račun državnim računovođama (officiales rationum). ${ }^{41}$ Ta je služba za financijski nadzor dužnosnika i izaslanika dokumentirana u izvorima od sredine 13. stoljeća, a 1282. već se specijalizirala i institucionalno razdvojila na one koji su kontrolirali „unutarnje” $\mathrm{i}$,„vanjske" službe. ${ }^{42}$

Knez se, prema prisezi, morao pobrinuti za pravovremeno ubiranje regalija za dužda i mletačku komunu. ${ }^{43}$ Promissio dužda Jacopa Tiepola iz 1229. i njegovih sljednika doista spominje njegova regalna prava iz dubrovačkog kneštva. ${ }^{44}$ Prema mletačko-dubrovačkim sporazumima iz 1232., 1236. i 1252., mletačkoj je komuni uime regalnih prava godišnje pripadalo 100 perpera, a duždu $12 .{ }^{45}$ To su vrlo niski iznosi i treba ih čitati u simboličnom ključu, kao izraz podložnosti višoj vlasti.

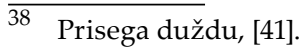

39 Prisega duždu, [13].

40 Obveza izrade pisanog izvješća uvedena je 1524. Vidi Commissiones et relationes Venetae, sv. I (prir. Sime Ljubić), Zagreb: JAZU, 1876., VI.

41 Prisega duždu, [34].

42 Archivio di Stato di Venezia, Guida generale (http://www.maas.ccr.it/h3/h3.exe/aguida/d52033, pristup 7. rujna 2017.).

43 Prisega duždu, [17, 21].

44 Listine I, dok. 74, str. 46; Le promissioni del doge di Venezia dalle origini alla fine del Duecento (prir. Gisella Graziato), Venezia: Comitato Pubblicazione delle Fonti relative alla Storia di Venezia, 1986. $18,34,54,74,95$.

45 Listine I, dok. 75, str. 48; dok. 80, str. 54; dok. 106, str. 84.
} 
Još se nekoliko glava prisege odnosi na financije. Mletački je Senat 1297. odlučio da će knez umjesto pristojbi od aptagi ubuduće primati paušal od 8 libara. ${ }^{46}$ Ustvari, zamjenu paušalom zatražili su i dubrovački izaslanici koju godinu ranije, a mletačke su vlasti još 1294 . iskazale spremnost na sporazum. ${ }^{47}$ Iz potonjeg dokumenta vidi se da je riječ o dvije pristojbe koje su se naplaćivale pri uspostavi sudskog založnog prava, u jednom slučaju na temelju dužnikova ritualnog padanja ničice, a u drugome na zahtjev vjerovnika (aptagi).$^{48}$ Odredba je unesena u prisegu u hipotetskom obliku (si placebit comuni Ragusii), odnosno ostavljeno je na volju dubrovačkoj komuni hoće li knezu isplaćivati pristojbe ili paušal. Ako nije došlo do grube greške pri transkripciji dokumenta o kneževim prihodima iz 1304., čini se da se ostalo na pristojbama, jer je knez od aptagi trebao primiti oko 25 puta viši iznos nego što bi iznosio paušal. ${ }^{49} \mathrm{U}$ tom je slučaju nejasno zašto je dubrovačka komuna odustala od vlastitog zahtjeva i za nju financijski vrlo povoljne zamjene paušalom. Neobično je također da u prisegu nije unesena srodna, a važnija odredba iz 1244. da će umjesto prihoda od novčanih kazni knez ubuduće primati paušal od 280 libara. ${ }^{50}$ Kako god bilo, prijelaz na paušale dio je procesa kojime dubrovački knez postaje dužnosnik s fiksnim prihodima, za što su bile zainteresirane obje strane: mletačke vlasti dobivale su jednostavniju financijsku shemu u kojoj se nije moralo vrebati teče li ubiranje pristojbi uredno, a dubrovačka se komuna riješila nezgodne financijske zainteresiranosti kneza za ishod sudskih postupaka, napose za kažnjavanje i izricanje globa.

Na sličan je način u prisezi 1308. izmijenjen okvir jurisdikcije dubrovačkog kneza nad Lastovom: sudbena je vlast prenesena na lastovsku zajednicu, a knez je „obeštećen” godišnjim paušalom. Vikaru koji je u njegovo ime upravljao otokom Lastovci su ubuduće trebali plaćati samo fiksnu plaću od 50 perpera. ${ }^{51}$

Nadalje, knez je prisezao da neće bez odobrenja središnjih vlasti u Veneciji (Vijeća četrdesetorice i Velikog vijeća) opraštati i ublažavati globe koje su izrekli njegovi prethodnici već da će se pobrinuti da se uberu, a također da će skrbi-

\footnotetext{
46 Listine I, dok. 276, str. 189; Prisega duždu, [29].

47

48

O pravnoj i ritualnoj strani postupka padanja ničice dužnika uoči litiskontestacije i institutu aptagi pisala sam detaljno u: Nella LONZA, Ritual padanja ničice i sudsko založno pravo srednjovjekovnog Dubrovnika, u: Liber amicorum. Zbornik radova posvećen Antunu Cvitaniću (ur. Zeljko Radić), Split: Književni krug Split i Pravni fakultet Sveučilišta u Splitu, 2016., 283-304, osobito 299-300.

49 Listine I, br. 319, str. 208

50 Codex diplomaticus Regni Croatiae, Dalmatiae et Slavoniae - Supplementa, sv. I (prir. Josip Barbarić i Jasna Marković), Zagreb: HAZU i Hrvatski državni arhiv, 1998., dok. 83, str. 121. Dokument je već pod pogrešnom godinom objavljen u Codex III, br. 276, str. 310.

51

Prisega duždu, [35].
} 
ti o izvršenju drugih kazni izrečenih kod ubojstva, krađe i izdaje. ${ }^{52}$ Budući da su 1244. globe prestale biti njegov izravni prihod, ${ }^{53}$ moglo se očekivati da će se knez manje trsiti oko njihova ubiranja, što je štetilo komuni, u čiju su se blagajnu prihodi otada slijevali. Glava o zabrani pomilovanja zajednička je gotovo svim prisegama kneževa ${ }^{54}$ i prati proces kojime se u rukama Vijeća četrdesetorice i Velikog vijeća postupno koncentrirao vrlo važan instrument „milosti” (gratia) koji je pravnom poretku osiguravao potrebnu fleksibilnost i omogućavao pragmatičnu politiku u kažnjavanju i drugim sferama javne vlasti. ${ }^{55}$

Knez također priseže da neće primati nikakvu „,uslugu" ${ }^{\prime \prime 56}$ niti dar (servicium vel donum) za vrijeme službe ni pola godine nakon njezina isteka, pod prijetnjom globe od dvostruke vrijednosti dara; pobrinut će se također da netko drugi ne primi poklon u njegovo ime, a u suprotnome ga vratiti. ${ }^{57}$ Ta se zabrana nije odnosila samo na darove lokalnog stanovništva nego i onog iz Dalmacije i slavenskog zaleđa, ${ }^{58}$ čime se željelo spriječiti „hvatanje” kneza u mrežu lokalnih i regionalnih moćnika te zaštititi njegovu nezavisnu poziciju i odanost mletačkoj državi.

Prisegom se kneza također obvezuje da će se za vrijeme trajanja funkcije suzdržati od bavljenja trgovinom i pobrinuti se da se u to ne upuštaju ni njegovi sinovi i članovi družine. ${ }^{59}$ Kao izuzetak od spomenutog pravila, bilo mu je dopušteno u poslove uložiti plaću (salarium), ali samo jednom godišnje, ${ }^{60}$ da se vi-

52 Prisega duždu, [22]

Načelnikovo pravo na prihode od globa poznavaoje i sustav podestatske uprave(Vittorio FRANCHINI, Saggio di ricerche sull'istituto del podestà nei comuni medievali, Bologna: Nicolo Zanichelli, 1912., 159). I u dalmatinskim gradovima koji nisu bili pod mletačkom vlašću globe u ranijem razdoblju pripadaju predstavniku više vlasti, a kasnije komuni. Vidi Lujo MARGETIĆ, O nekim osnovnim značajkama pokretanja kaznenog postupka u srednjovjekovnim dalmatinskim općinama, Rad HAZU, 35, 1997., 12-13, 17. To jasno ukazuje da nije riječ ni o kakvom financijskom iscrpljivanju komune, već o nečemu što se smatralo razboritom naknadom za poglavareva sudbena zaduženja.

Primjerice za Kopar (Le commissioni ducali, 112), Izolu (175), Piran (192), Rovinj (202), Zadar (228).

Dennis ROMANO, Quod sibi fiat gratia: adjustment of penalties and the exercise of influence in early Renaissance Venice, The Journal of Medieval and Renaissance Studies, 13, 1983., 252. Još 1255. ograničena su prava dužda i njegovih vijećnika na davanje pomilovanja za globe (ibidem, 253).

Teško je zaključiti je li riječ o usluzi ili o „službi” u smislu vazalne obveze. Zabranu primanja usluge/ službe sadrži i duždeva prisega. Le promissioni del doge di Venezia, 11.

Prisega duždu, [15]. Nešto kraća zabrana primanja dara za zadarskog kneza formulirana je 1256 (Deliberazioni II, 334).

58 Prisega duždu, [16].

59 Prisega duždu, [6-8]. Zabrana trgovanja unesena je i u prisegu kneževa pomoćnika u Dubrovačkom statutu II, 2. Zadarskom knezu trgovanje je zabranjeno 1263. (Deliberazioni II, 335), što upućuje na to da je tada ili nedugo kasnije mogla biti formulirana zabrana za dubrovačkog kneza.

60 Prisega duždu, [7]. U sličnom duhu, u Statutu se kneževom pomoćniku prisegom dozvoljava uložiti u poslove „što mu pretekne od plaće" (Dubrovački statut II, 2). 
šekratnim aktiviranjem istog iznosa u nekoj domeni s brzim obrtom kapitala ne bi probilo prihvatljive okvire. Zabrana je kasnije protegnuta na uzimanje zajma od Dubrovčana ili Mlečana ako se kapital ulaže u Dubrovniku. ${ }^{61}$

Tijesno povezivanje s lokalnom sredinom, koje bi moglo dovesti u pitanje lojalnost mletačkim vlastima, nastojalo se suzbijati i zabranom iz 1354. svim kneževima i njihovim potomcima da za vrijeme mandata i godinu dana nakon toga zaključe $\mathrm{u}$ tom gradu brak ili ishode nadarbinu (prebenda vel beneficium) za sebe ili drugog. ${ }^{62}$

Odgovornost za kršenje naputka u nepoznatom je trenutku protegnuta na suprugu i djecu, koji su pratili kneza na njegovu dužnost, i na kneževe pomoćnike. Ogriješe li se o naputak, protiv njih se u Veneciji trebao povesti postupak po tužbi općinskog odvjetnika (advocator comunis), ${ }^{63}$ kakav se inače provodio pred Vijećem umoljenih i Vijećem četrdesetorice zbog kneževskih zlouporaba. ${ }^{64}$ Time su zaokružene zabrane i ograničenja postupaka samoga kneza, njegove biološke obitelji i družine, koji bi tog dužnosnika mogli gurnuti u sukob interesa. ${ }^{65}$

Kao što je već spomenuto, pravni izvori koji se spominju u prisezi pripadaju normativnom sustavu Dubrovnika prije donošenja Statuta 1272. Knez se obvezuje da će poštovati sporazume (pacta) između Dubrovnika i Venecije. ${ }^{66} \mathrm{U}$ prisezi duždu kazneni statut iz vremena kneza Tiepola određuje se kao capitula que fuerint scripta et determinata tempore regiminis nobilis viri Iohanis Teupuli, comitis Ragusii, ${ }^{67}$ što potvrđuje pretpostavku da je riječ o manjoj normativnoj cjelini razrađenoj u glave. ${ }^{68} \mathrm{U}$ svim slučajevima koji njome nisu regulirani prisega daje knezu ovlast suditi prema vlastitoj prosudbi (liberum arbitrium), što znači da nije

\footnotetext{
61 Prisega duždu, [28]. Vidi niže.

62

Prisega duždu, [46].

63
}

64 Par takvih procesa čuva se u Archivio di Stato di Venezia, fond Avogaria di Comun, serija Raspe, reg. 3642, f. 20v (protiv creskog kneza, 1341.) i f. 63v-64r (protiv zadarskog kneza, 1357.). Proces u kojem je podestat Hvara i Brača osuđen na globu zbog povrede časti i dobrobiti Venecije i kršenja svog naputka (contra formam sue commissionis) prikazao je Bariša KREKIĆ, O neprilikama dvojice mletačkih potestata Hvara u prvoj polovini XIV veka, Zbornik Filozofskog fakulteta u Beogradu, 11/1, 1970. (Spomenica Jorju Tadiću), 309. O nadležnosti općinskog odvjetništva (Avogaria di comun) vidi Andrea Da Mosto, L'Archivio di Stato di Venezia, Indice generale, storico, descrittivo ed analitico, sv. I, Roma: Biblioteca d'arte editrice, 1937., 68.

O regulaciji potencijalnog sukoba interesa u 13.-15. stoljeću, vidi Donald E. QUELLER, The Venetian Patriciate: Reality versus Myth, Urbana-Chicago: University of Illinois Press, 1986., 184-185.

Prisega duždu, [9]. Ti su sporazumi zaključeni 1232, 1236 i 1254.

67

Prisega duždu, [10]. Za taj se izvor znalo iz kneževe prisege komuni iz 1254

LONZA, Dubrovački statut, 18 i ondje citirana starija literatura. 
vezan pravnim normama već samo moralnim i vjerskim obzirima. ${ }^{69}$ Budući da Tiepolov kazneni statut nije sačuvan, nepoznato je koliko su široke ovlasti odista ostajale u kneževim rukama. Važno je naglasiti da diskrecijska prava kneza ne treba interpretirati kao namjerni potez mletačkih vlasti na štetu dubrovačke zajednice. Naime, norme koje „zatvaraju” pravni poredak - bilo da su upućivale na slobodnu prosudbu magistrata, ius commune ili neki drugi izvor - bile su pravno-tehnički nužne u svim sustavima koji su imali kazuistički oblikovane norme, s općenito nižim stupnjem generalizacije. U statutima „mletačkoga kruga” uputa na opće europsko pravo (ius commune) otpadala je iz političkih razloga, jer se htjelo istaknuti neovisnost o carskoj vlasti, koja je tu baštinu prigrlila, i naglasiti samosvojnost mletačkog prava. ${ }^{70}$ Stoga se $\mathrm{u}$ hijerarhiji pravnih izvora redovito kao zadnje rješenje navodi arbitrium, ${ }^{71}$ pa tako i u mletačkom Kaznenom statutu (Promissio maleficii) iz 1232. ${ }^{72}$ koji je vjerojatno bio neposredni uzor za ovlasti dubrovačkog kneza u kaznenom suđenju. ${ }^{73}$

Kao i u mnogim drugim primjerima prisegâ duždu iz istog rukopisa, dubrovački knez obećaje da će skrbiti da se imovina Mlečana koji umru bez oporuke očuva i otpremi u Veneciju. ${ }^{74}$ Zaštita imovine mletačke komune i njezinih građana izvan Venecije jedan je od postulata mletačke politike, izražen i u samoj duždevoj prisezi. ${ }^{75}$

Kneževo obećanje da neće priječiti prijevoz pšenice i drugih žitarica za Veneciju, pače, da će pomoći da se on što brže ostvari, ${ }^{76}$ može se lako razumjeti iz perspektive vječite skrbi oko uvoza tih osnovnih namirnica, kojima je osobito oskudijevalo uže područje Venecije. U srednjovjekovnim talijanskim gradovima

$\overline{69}$ Mletački statut iz 1242. u prologu podsjeća suce da pri slobodnoj prosudbi trebaju imati pred očima Boga i misliti na polaganje računa na Posljednjem sudu (disponant nostri iudices, sicut iustum et equum eorum providentie apparebit, habentes Deum ante oculos sue mentis, sic ut in die districti examinis coram tremendo iudice digne possint reddere rationem). Roberto CESSI, Gli statuti veneziani di Jacopo Tiepolo del 1242 e le loro glosse, Memorie del R. Istituto Veneto di Scienze, Lettere ed Arti, 30, 2, 1938., 5-6.

ZORDAN, Ordinamento giuridico veneziano, 205-213; za Dubrovnik LONZA, Dubrovački statut, 15.

71 O arbitriumu u mletačkoj pravnoj kulturi vidi ZORDAN, Ordinamento giuridico veneziano, 210; ORLANDO, Politica del diritto, 22-23.

72 Liber promissionis maleficii, c. 29 (Leggi criminali del Serenissimo Dominio Veneto, Venezia: Stampatori Ducali, 1751.).

73 Lamberto PANSOLLI, La gerarchia delle fonti di diritto nella legislazione medievale veneziana, Milano: Giuffrè, 1970., 274.

74 Prisega duždu, [11]; isto i u drugim prisegama: za načelnika Pirana (Le commissioni ducali, 190) i zadarskog kneza (228).

75 Le promissioni del doge, 17 (prisega Jacopa Tiepola).

76 Prisega duždu, [23]; vrlo slično u prisezi koparskog kneza (Le commissioni ducali 112). 
o nabavi žita uvijek je brinula javna vlast, jer se znalo da oskudica može lako ugroziti političku stabilnost. ${ }^{77}$

Posebno je detaljna odredba o aktivnom sprječavanju prodaje „vojnih sirovina" (konji, oružje, željezo, drvo i dr.) Saracenima. ${ }^{78}$ Pokušaji zabrane trgovine sa Saracenima imaju dugu povijest svjedočeći ustvari o nemoći papinske vlasti pri uspostavi efikasnog i širokoprihvaćenog embarga, jer su se trgovački gradovi ispričavali štetom koju bi od toga imali i uglavnom su pristajali na prekid trgovačkih veza samo za dobra koja za Saracene mogu imati vojnu ili stratešku važnost. ${ }^{79}$ Venecija je u nizu navrata, počevši od 10. stoljeća, donosila odredbe gornjega tipa, s ponešto različitim popisom zabranjene robe. ${ }^{80}$

Prisezi dubrovačkog kneza dodane su još neke odredbe koje su unesene $u$ sve obrasce iz ovoga sveska: odredba o sankcioniranju pronevjera iz $1265 .{ }^{81} \mathrm{za}-$ brana kockanja, osim igranja šaha i backgammona iz 1292.;2 zabrana prisiljavanja ribara na prodaju ribe knezu; ${ }^{83}$ dužnost pregledavanja nenaoružanih brodica prenose li dragocjenosti, pod prijetnjom zapljene; ${ }^{84}$ zabrana krijumčarenja soli. ${ }^{85}$ Svim prisegama dodan je također niz glava o izgonu pojedinaca koji su se teško ogriješili o mletačke propise. ${ }^{86}$

77 Gerhard RÖSCH, Le strutture comerciali, u: Storia di Venezia, sv. II - L'età del comune (ur. Giorgio Cracco i Gherardo Ortalli), Roma: Istituto dell'Enciclopedia italiana, 1995. (http://www.treccani. it/enciclopedia/l-eta-del-comune-gli-ordinamenti-le-strutture-commerciali_\%28Storia-di-Venezia\%29/, pristup 6. listopada 2017.).

Prisega duždu, [27].

O tom pitanju vrlo detaljno Stefan K. STANTCHEV, Embargo: The Origins of an Idea and the Implications of a Policy in Europe and the Mediterranean, ca. 1100-1500, doktorska disertacija, University of Michigan, 2009. (https:/deepblue.lib.umich.edu/bitstream/handle/2027.42/63734/ stan?sequence=1; pristup 4. listopada 2017).

80 Vidi ZORDAN, Ordinamento giuridico veneziano, 177-178; Gherardo ORTALLI, Venice and Papal Bans on Trade with the Levant: The Role of the Jurist, Mediterranean Historical Review, 10, 1-2, 1995., 242-258.

81 Prisega duždu, [38].

82 Prisega duždu, [24]. Tabulae ili ad tabulerium, preteča današnjeg backgammona, bila je vrlo popularna igra u srednjem vijeku. Budući da, kao i šah, traži razmišljanje, često je bila izuzeta od zabrana igara na sreću. Vidi Sabine Florence FABIJANEC, Ludus zardorum: moralni i zakonski okviri kockanja na Jadranu i u srednjem vijeku, u: Na rubu zakona: društveno i pravno neprihvatljiva ponašanja kroz povijest (ur. Suzana Miljan), Zagreb: Hrvatski studiji Sveučilišta u Zagrebu, 2009., 25-26.

Prisega duždu, [31]. Obveze ribara prema knezu regulira Dubrovački statut, I, 10.

Prisega duždu, [43].

85

Prisega duždu, [44].

86

Prisega duždu, [39, 45, 47, 48]. 


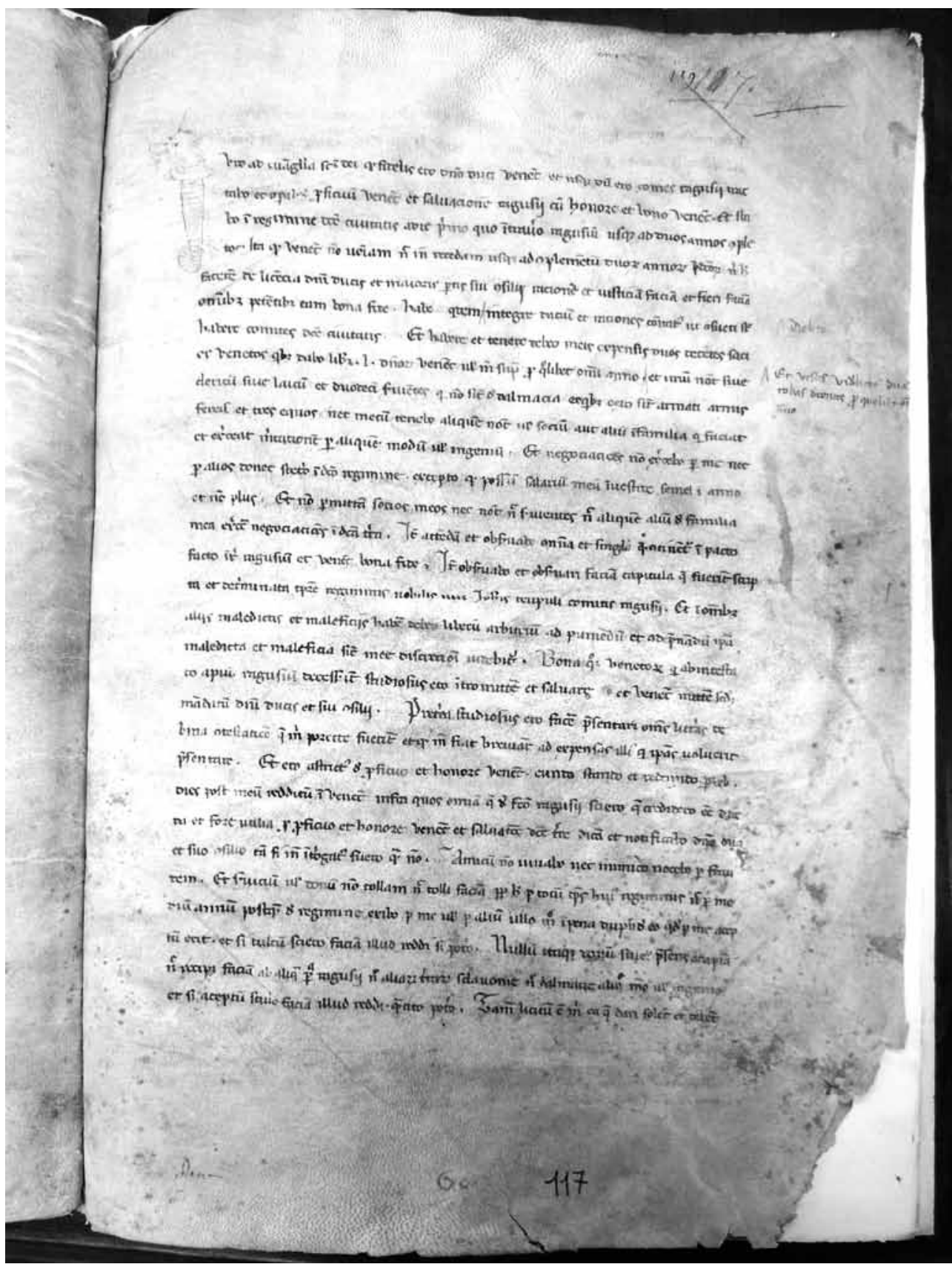

Slika 2. Početak obrasca prisege dubrovačkog kneza duždu. Archivio di Stato di Venezia, Collegio, Formulari di commissioni, reg. 1, f. 117r. 


\section{Odnos prisege duždu i naputka (commissio)}

Pošto je položena prisega duždu, knezu se predavao primjerak naputka (commissio) da ga prouči i ponese sa sobom u Dubrovnik kako bi poslužio u slučaju kakve dvojbe o njegovim ovlastima. ${ }^{87}$ Očitujući se 1313. na molbu Lovra Bubagne glede zakupa lastovskog kneštva, ${ }^{88}$ predstavnici dubrovačke komune odista konzultiraju i citiraju dvije odredbe iz naputka. ${ }^{89}$

Premda nije sačuvan nijedan primjerak isprave-naputka za dubrovačkog kneza, u dokumentima iz mletačkog i dubrovačkog arhiva pohranjene su odluke kojima se on dopunjuje, mijenja ili neka odredba privremeno stavlja izvan snage, što pruža uvid u dio njegova sadržaja. U odredbu iz naputka po kojoj se knez nije smio udaljiti iz Dubrovnika mletačke vlasti 1276. dodaju izuzetak da ubuduće može do osam dana otići s dubrovačkog područja radi pribivanja stanku. ${ }^{90}$ Prije 1300. u naputku je stajala odredba o teretu dubrovačkog kneza od 100 libara godišnje ako se bude skupljao novac za vojsku. ${ }^{91}$ Dubrovačko Veliko vijeće obvezuje se 1303. da će knezu nadoknaditi svu pretrpljenu štetu bude li zbog nabave žita potpao pod globu iz svojeg naputka (si dictus comes caderet in aliquam penam secundum formam sue commissionis), ${ }^{92}$ što odražava s kakvom su se mukom nabavljale žitarice u obje sredine. Dopunom naputka iz 1305. mletačke vlasti zabranjuju knezu kojem je istekao mandat napustiti Dubrovnik prije no što stigne njegov zamjenik. ${ }^{93} \mathrm{U}$ odredbi koja je početkom 14 . stoljeća dodana Dubrovačkom statutu spominje se da knežev naputak (commissio comitis) upućuje na statut Giovannija Tiepola, prema kojem ubojstvo treba kazniti smrtnom kaznom, ${ }^{94}$ no mletačke vlasti ipak 1308. dozvoljavaju odstupanje od toga da bi se zagladio sukob sa srpskim kraljem. ${ }^{95}$ Odlukom mletačkog Velikog vijeća u

\footnotetext{
87 Libri reformationum, sv. I (prir. Ivan Kr. Tkalčić), Monumenta spectantia historiam Slavorum meridionalium, sv. X, Zagreb: JAZU, 1879., 34.

88

89

90 (I, 4). Ovdje bi mogla biti riječ o usklađenju naputka sa Statutom, ali je mnogo vjerojatnije da je tek tada u Statut unesen taj detalj. Statut je donesen 1272., no pri izradi najstarijeg sačuvanog rukopisa iz sredine 14. stoljeća u tekst su već integrirane izmjene do kojih je u međuvremenu došlo, a ovo bi mogla biti jedna od njih.


naputak se 1312. dodaje da knez ne smije uzeti zajam od Dubrovčanina, a ni od Mlečanina ako se koristi u Dubrovniku. ${ }^{96}$ Dubrovačkom se knezu 1316. dopušta izabrati za pomoćnika (socius) bilo Mlečanina bilo stranca, makar to bilo suprotno slovu naputka. ${ }^{97}$ Naputak se navodi 1313. u očitovanju dubrovačkih vlasti o zakupu lastovskih prihoda, te se spominje da je u jednoj njegovoj točki (punctum commissionis) točno navedeno koji mu prihodi pripadaju. ${ }^{98}$ Godine 1338. dodaje se naputku vrlo važna odredba da knežev notar svoje spise mora ostaviti u Dubrovniku. ${ }^{99}$ Pet godina kasnije Senat odlučuje u naputak unijeti dužnost skrbi o dubrovačkim galijama. ${ }^{100}$ Potkraj mletačke vlasti, godine 1353., potvrđuje se i razrađuje odredba naputka prema kojoj je knez morao slati jednog od svojih pomoćnika na Lastovo kako bi ondje dijelio pravdu. ${ }^{101}$

Usporedba s tekstom prisege duždu navodi na siguran zaključak da je to u osnovi jedan te isti tekst koji se, uz nužne stilske prilagodbe, izrađivao u dva oblika. ${ }^{102}$

\section{Kneževa vjerodajnica}

Knez je od dužda primao vjerodajnicu, koju je predavao pri dolasku na novu dužnost. ${ }^{103}$ Sačuvani primjerci nemaju posve istu formulu, odnosno oni iz 50ih godina 13. stoljeća razlikuju se ponešto od ranijih. ${ }^{104} \mathrm{U}$ vjerodajnici stoji ime novoga kneza, da mu je mandat dvije godine i da se od Dubrovčana traži i moli da ga prime i štuju te vjerno slušaju njegove naredbe (precepta, mandata) prepu-

\footnotetext{
${ }^{96}$ Listine I, br. 407, str. 262.

97 Listine I, br. 448 , str. 288

98 Libri reformationum I, 20.

99 Listine II, br. 47 , str. 30

100 Venezia - Senato, Deliberazioni miste, sv. VIII (reg. XXI) (prir. Claudio Azzara i Laura Levantino) Venezia: Istituto Veneto di Scienze, Lettere ed Arti, 2006., br. 455, str. 236. O držanju galije vidi također starije dokumente citirane u: Šime LJUBIĆ, Ob odnošajih dubrovačke sa mletačkom republikom tja do g. 1358., Rad JAZU, 5, 1868., 103.

101 Listine o odnošajih između južnoga slavenstva i Mletačke Republike, sv. III (prir. Sime Ljubić), Monumenta spectantia historiam Slavorum Meridionalim, sv. III, Zagreb: JAZU, 1872., br. 390, str. 261.

102 Usp. izvore citirane u prethodnom odlomku i prisegu duždu u prilogu.

103 Diplomatička forma reproduciranog primjerka zove se litterae clausae, obično s visećim olovnim pečatom na vrpci od kudjelje. Marco POZZA, La cancelleria, u: Storia di Venezia, sv. II - L'Età del Comune (ur. Giorgio Cracco i Gherardo Ortalli), Roma: Istituto della Enciclopedia italiana, 1995., 355-358. Isprava za kneza Giovannija Giustiniana (slika 3) u Codexu je pogrešno datirana u 1250. (Codex IV, br. 370, str. 427). Taj datum ustvari odgovara 1249. godini, jer je primijenjen bizantski stil računanja godine.

104 Codex IV, br. 322, str. 362-363; br. 370, str. 427; Codex - Supplementa I, br. 172, str. 219; br. 193, str. 239240.
} 
štajući mu ovlasti u upravljanju gradom kao i njegovim prethodnicima; tome se redovito dodaje "od vremena Ivana Tiepola”, što se referira na novi model izravnog upravljanja Dubrovnikom koji je tada uveden.

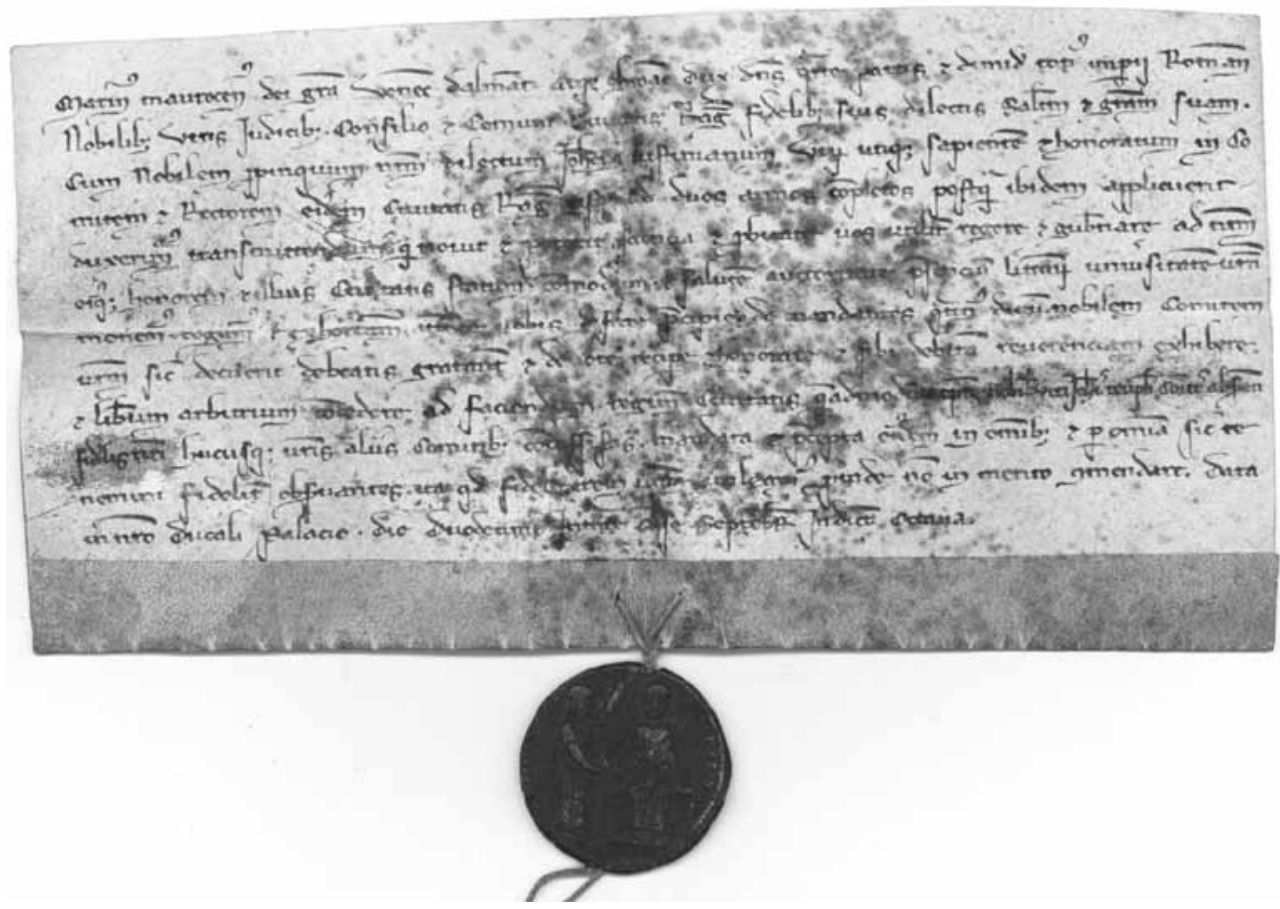

Slika 3. Vjerodajnica kneza Giovannija Giustiniana s visećim duždevim pečatom iz 1249. Državni arhiv u Dubrovniku, ser. 76, Acta et diplomata saec. XIII, br. $118 \mathrm{~b}$.

\section{Kontekst kneževe prisege komuni: instalacija kneza u Dubrovniku}

Obred instalacije mletačkog kneza zapisan je u Statutu iz 1272. ${ }^{105}$ Počinjao je prisegom pred pukom okupljenim na trgu, o čijem će sadržaju biti riječi u nastavku. Nakon toga knez je „iz ruku komune”, tj. od njezinih predstavnika (per manus comunis Ragusii), primao stijeg s likom gradskog patrona, sv. Vlaha (vexillum Beati Blasii). Prisega s predajom stijega bila je konstitutivni element investiture, kojim je knez preuzimao svoju funkciju i upravu nad Dubrovnikom

$\overline{105}$ Dubrovački statut, I, 1 . 
(et taliter investitur... de comitatu et regimine Ragusii). Potom je odlazio do katedrale, gdje su ga predstavnici crkvenih vlasti dočekivali s kadionicom, svetom vodom i Evanđeljem. U stolnici je knez pred glavnim oltarom ponovno preuzimao Parčev stijeg te polagao drugu prisegu, da će poštivati crkvene interese i običaje, koji su detaljnije popisani u sljedećim statutarnim odredbama. ${ }^{106}$ Kanonici su mu na to pjevali laude, ${ }^{107}$ a on im je uzvraćao simboličnim novčanim darom. Napokon, u trećem dijelu obreda instalacije Dubrovčani (homines Ragusii) prisezali su vjernost knezu i duždu prema uobičajenoj zavjernici (sacramentum fidelitatis), koja je također unesena u Statut. ${ }^{108}$ Njome se jamčilo poštivanje kneževih odluka, a najdulji dio odnosi se na suzdržavanje od zavjera protiv mletačke vlasti. Mletačko je Veliko vijeće 1280. odlučilo da će dužd gradovima razaslati stijeg sv. Marka da posluži pri polaganju te kolektivne prisege, ${ }^{109}$ pa je vjerojatno taj simbolični element tada uveden i u Dubrovniku. Kolektivna prisega vjernosti (fidelitas) bila je, inače, tipičan feudalni element koji je prešao u praksu talijanskih gradova u 13. stoljeću, posebno onih pod carskom vlašću s podestatskim modelom uprave, ${ }^{110} \mathrm{a}$ nipošto nekakav mletački „ritual poniženja”. ${ }^{11}$

Elementi kneževe investiture ocrtavaju sličan odnos komune i njezina upravljača kakav postoji u mnogim komunalnim sredinama na talijanskom prostoru. Međutim, specifična je dvostruka prisega dubrovačkog kneza komuni i vrhu lokalne Crkve, i s time povezana dvostruka predaja barjaka sv. Vlaha.

$\overline{106}$ Dubrovački statut, I, 2.

107 O bizantskoj tradiciji pjevanja laudi u dalmatinskim gradovima vidi Marko PETRAK, Nobile hoc Romani Imperii monumentum: Laudes imperiales in Byzantine Dalmatia, Revue Internationale des Droits de l'Antiquité, 63, 2016., u tisku.

108 Dubrovački statut, II, 3. S ovime nema veze polaganje prisege vjernosti duždu 16. veljače 1329., do kojega je došlo nekim zasada nerazjašnjenim konkretnim povodom. Dukal je knez dao pročitati najprije u Velikom vijeću, čiji su članovi morali pojedinačno na Sv. Pismo prisegnuti vjernost. Zatim je objavljen i okupljenom puku, koji je „spontano" počeo klicati duždu, prisegnuo vjernost duždu i mletačkoj komuni i „veselo" primio na dar stijeg Sv. Marka (recipientes letissime vexillum beati Marchi evangeliste eis presentatum et datum pro parte ipsius d. ducis). Libri reformationum, sv. II (prir. Ivan Kr. Tkalčić), Monumenta spectantia historiam Slavorum meridionalium, sv. XIII, Zagreb: JAZU, 1882., 322.

109 Deliberazioni II, 40.

110 V. Enrica SALVATORI, I giuramenti collettivi di pace e alleanze nell'Italia comunale, u: Legislazione e prassi istituzionale nell'Europa medievale (secoli XI-XV) (ur. Gabriella Rossetti), Napoli: GISEMLiguori, 2000. (http://eprints.adm.unipi.it/708/1/giuramenti.htm, pristup 19. listopada 2017.). Za Split vidi Mirjana MATIJEVIĆ SOKOL, Regimen latinorum arhiđakona Tome u teoriji i praksi, Historijski zbornik, 52, 1999., 25.

111 Usp. Zdenka JANEKOVIĆ RÖMER, Ragusan Views of the Venetian Rule, u: Balcani occidentali, Adriatico e Venezia fra XIII e XVIII secolo / Der westliche Balkan, der Adriaraum und Venedig (13.18. Jahrhundert) (ur. Gherardo Ortalli i Oliver Jens Schmitt), Venezia-Wien: Österreichische Akademie der Wissenschaften i Istituto Veneto di Scienze, Lettere ed Arti, 2009., 54-55. 
Investitura predajom stijega (per vexillum) uvedena je u Veneciji u prvoj polovici 12. stoljeća, usporedno s duždevom nastupnom prisegom (promissio ducalis); po drugi put patronov stijeg predavali su duždu svećenici bazilike sv. Marka pred glavnim oltarom, a on je prisezao da će štititi prava svečeve crkve. ${ }^{12}$ Ujedno se u mletačkoj praksi još od 11. stoljeća na duždevu prisegu nastavljala uzvratna prisega vjernosti stanovnika. ${ }^{113}$ Dakle, nema dvojbe da su dvojni oblik dubrovačkog rituala investiture kneza i prisega Dubrovčana kreirani po uzoru na tijek instalacije mletačkog dužda. ${ }^{114}$

\section{Kneževa prisega komuni}

U dubrovačkom arhivu sačuvane su isprave s kneževom nastupnom prisegom komuni iz 1237., 1238., 1240., 1242., 1244., 1245., 1247. i $1254 .{ }^{115}$

Najstarija je ona Giovannija Tiepola, duždeva sina, koji je na čelu Dubrovnika ostao samo godinu dana. S njime su ustvari mletačke vlasti prestale davati kneževske funkcije u zakup i uspostavile su izravnu upravu (regimen) s knezom izabranim na kraći rok, kakvu je odranije imao Zadar. Tekst Tiepolove prisege postao je obrazac koji se prepisivao u novim zgodama, tako da su svi kasniji primjerci isti, s time što je $u$ najmlađu sačuvanu prisegu iz 1254. (ili jednu od njezinih nesačuvanih prethodnica, onu za kneza Giovannija Giustiniana iz 1249. ili Marsilija Zorzija iz 1252.) ubačeno nekoliko rečenica.

Prisega se svaki put izrađivala $\mathrm{u}$ formi javne isprave, i to $\mathrm{u}$ dva primjerka, po jednome za kneza i za komunu. ${ }^{116}$ Imala je formu prerezanog dokumenta (charta

$\overline{112}$ Za diskusiju o tim pitanjima vidi Gina FASOLI, Liturgia e ceremoniale ducale, u: Venezia e il Levante fino al secolo XV, sv. I (ur. Agostino Pertusi), Firenze: Leo S. Olschki editore, 1973., 266-268, 294; Agostino PERTUSI, Quedam regalia insignia: ricerche sulle insegne del potere ducale a Venezia durante il medioevo, Studi veneziani, 7, 1965., 72-73; Staale SINDING LARSEN, Christ in the Council Hall: Studies in the Religious Iconography of the Venetian Republic, Roma: L'Erma, 1974., 159-166; Edward MUIR, Civic Ritual in Renaissance Venice, Princeton: Princeton University Press., 1981., 253.

O takvoj praksi 1071. svjedoči očevidac (fidelitatis iuramenta a populo recepit). Giorgio RAVEGNANI, Insegne del potere e titoli ducali, u: Storia di Venezia, sv. I - Età ducale (ur. Lelia Cracco Ruggini, Massimiliano Pavan, Giorgio Cracco i Gherardo Ortalli, Roma: Istituto dell'Enciclopedia italiana, 1992 (on-line: http://www.treccani.it/enciclopedia/eta-ducale-le-testimonianze-insegne-del-poteree-titoli-ducali_\%28Storia-di-Venezia\%29/, pristup 3. studenog 2017).

Detaljnije u: Nella LONZA, Kazalište vlasti: Ceremonijal i državni blagdani Dubrovačke Republike u 17. i 18. stoljeću, Zagreb-Dubrovnik: Zavod za povijesne znanosti HAZU u Dubrovniku, 2009., 7779.

Codex diplomaticus Regni Croatiae, Dalmatiae et Slavoniae, sv. IV (prir. Tadija Smičiklas), Zagreb: JAZU, 1906., br. 28, str. 32; br. 53, str. 60, br. 108, str. 119; br. 143, str. 159; br. 210, str. 241; br. 248, str. 283; br. 291, str. 327-328.

De hoc autem sacramento sunt due carte similes, hec et alia. Acta et diplomata saec. XIII, br. 244. Vidi C. JIREČEK i V. BOGIŠIĆ, Prolegomena, u: Liber statutorum civitatis Ragusii, LXVII-LXIX. 
partita), odnosno isti je tekst prepisan dvaput na pergameni koja je presječena po krupno ispisanim slovima $\mathrm{u}$ sredini, tako da se lako moglo provjeriti vjerodostojnost teksta i otkloniti opasnost da je riječ o krivotvorini. ${ }^{117} \mathrm{U}$ Dubrovačkom arhivu sačuvani su jamačno primjerci koji su trebali pripasti komuni, a za prisegu kneza iz 1238. slučajno raspolažemo s obje isprave (slika 4).

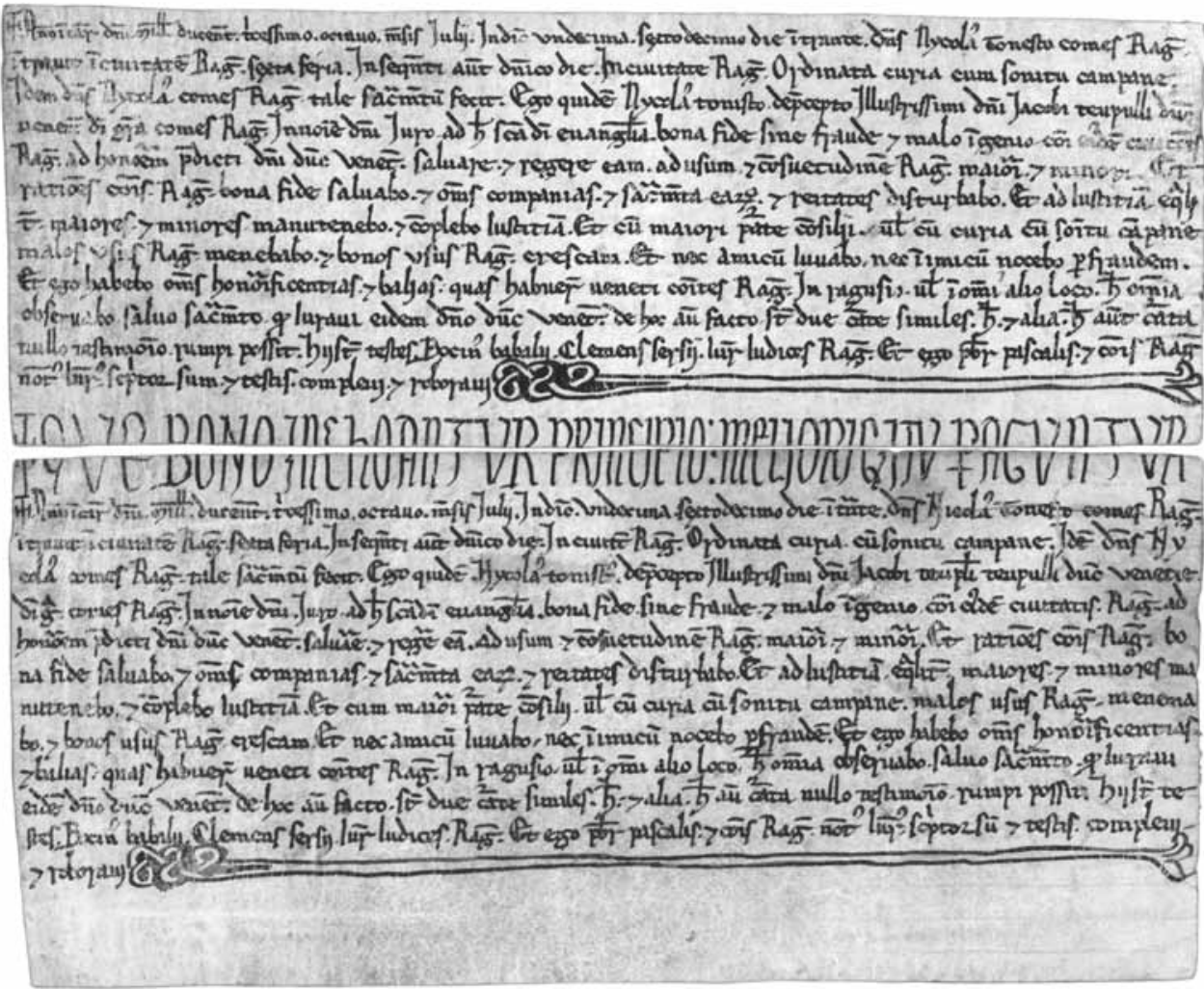

Slika 4. Prisega dubrovačkog kneza iz 1238. Državni arhiv u Dubrovniku, ser. 76, Acta et diplomata saec. XIII, br. 67.

117 Susreće se također izraz chirographum, s pomakom od originalnog značenja „vlastoručne isprave". Takve se „ovjere” bilježe u Engleskoj već sredinom 9. stoljeća. U Italiji su ih najviše rabili trgovci za privatne dokumente, a od kancelarija ona u Genovi. Vidi Cristina CARBONETTI VENDITELLI, 'Duas cartas unius tenoris per alphabetum divisas scripsi': Contributo a una geografia delle pratiche documentarie nell'Italia dei secoli XII e XIII, Scrineum Rivista, 10, 2013., 215-245; također Jakov STIPIŠIĆ, Pomoćne povijesne znanosti u teoriji i praksi, Zagreb: Školska knjiga, 2. izdanje, 1985., 152-153. 
Prisegom se knez obvezivao komuni da će upravljati Dubrovnikom i čuvati njegove interese $\mathrm{u}$ dobroj vjeri i bez himbe. ${ }^{118}$ Pri tome se trebao oslanjati na lokalne običaje, no imajući uvijek pred očima čast mletačkoga dužda. Obećavao je da će sprječavati zavjere, potiskivati loše običaje i poticati dobre, da će pravdu čuvati i dijeliti pravedno svim slojevima ${ }^{119}$ i da neće pogodovati prijatelju ni nauditi neprijatelju. U prisegu je ponešto pravno-tehnički nespretno dodano i njegovo pravo na sve časti i ovlasti koje su pripadale i drugim mletačkim kneževima u Dubrovniku i izvan njega. Tekst prisege dubrovačkoj komuni nije samo znatno kraći od prisege duždu nego je i mnogo općenitije stiliziran.

Tekst je dvadesetak godina ostao nepromijenjen dok nije 1254. proširen s nekoliko umetnutih elemenata. ${ }^{120}$ Određeno je da kontradiktorne „statute" treba interpretirati vodeći se interesima dubrovačke komune. Ovdje, dakako, nije riječ o statutarnoj zbirci (Statutu), koja je proglašena tek dvadesetak godina kasnije, nego o pojedinim statutima (aliquid statutorum, kako se kaže u tekstu), to jest zakonima koji su se odnosili na neko određeno pitanje i bilježili u obliku javne isprave. ${ }^{121} \mathrm{U}$ prisezi se govori o takvom "statutu” za kazneno pravo iz vremena kneza Giovannija Tiepola i o kažnjavanju drugih zločina na temelju slobodne prosudbe, o čemu je već bilo riječi. Knez je također prisezao da neće dozvoliti da mu nadbiskup i kanonici nametnu nove obveze $\mathrm{u}$ korist prvostolnice povrh onih već preuzetih zasebnom prisegom. ${ }^{122}$ Napokon, $u$ kneževu prisegu komuni iz 1254. ušlo je da knez vino za sebe i svoju družinu smije nabavljati otkud mu drago. Ovdje je opet riječ o kneževu pravu, a ne o ovlasti, tako da je i taj element „strano tijelo" u njegovoj prisezi.

$\overline{118}$ Vidi citirane tekstove prisega 1237.-1247.

119 Prema analizama Q. Skinnera o značenju pojma aequitas kod Cicerona i u srednjovjekovnoj političkoj misli, naglasak je na ublažavanju razlika i društvenih napetosti među slojevima. Vidi Quentin SKINNER, Visions of Politics, II - Renaissance Virtues, Cambridge itd.: Cambridge University Press, 2002., 49. Nije sasvim jasno je kako se riječi maiori et minori povezuju s ostatkom teksta. Priređivač je kod Tiepolove prisege dodao „(consilio)”, a kod Tonistove prisege pogrešno transkribirao maiorem et minorem. Kompilator Statuta taj je dio ispustio. Inače, maiores i minores su uobičajene odrednice za društvene slojeve u dalmatinskim komunama. Tomislav RAUKAR, Hrvatsko srednjovjekovlje: prostor, ljudi, ideje, Zagreb: Školska knjiga i Zavod za hrvatsku povijest Filozofskog fakulteta u Zagrebu, 1997., 196-197. U Veneciji se srodno nazivlje (maiores, mediocres, minores) rabi već u izvorima iz 10. stoljeća, a u tekstu duždeve Promissio u sintagmi koja je očito bila uzor za dubrovački tekst (omnes autem homines Veneciarum maiores et minores equaliter portabimus in racione). ZORDAN, Ordinamento giuridico veneziano, 178; Le promissioni del doge, 5, 16.

120 Prošireni tekst objavili su JIREČEK i BOGIŠIĆ, Prolegomena, LXIX. Začudo, u Codexu stoji netočan navod da je tekst isti kao kod ranijih prisega (usp. Codex IV, 567).

121 Detaljnije vidi LONZA, Dubrovački statut, 16-17.

122 Prisega crkvenom vrhu da će se obdržavati običaji i interesi katedrale bila je sastavni dio obreda instalacije kneza, opisan u Statutu (I, 1). Sadržaj običaja koje je knez dužan poštivati iznesen je u I, 2. 
Pri izradi statuta (1272.) tekst iz tih prisega-isprava uvršten je u statutarnu glavu II, 1. Zanimljivo je da pri tome nije korištena recentnija, potpunija verzija iz 1254. već se kompilator poslužio starijom varijantom. Nakon izrade Statuta, isprave o prisezi postale su suvišne, pa se više nisu izrađivale. Prisezalo se naime polaganjem ruke na to mjesto u službenom prijepisu Statuta, što se jasno vidi po pohabanosti rukopisa iz 1342. (slika 5). ${ }^{123}$

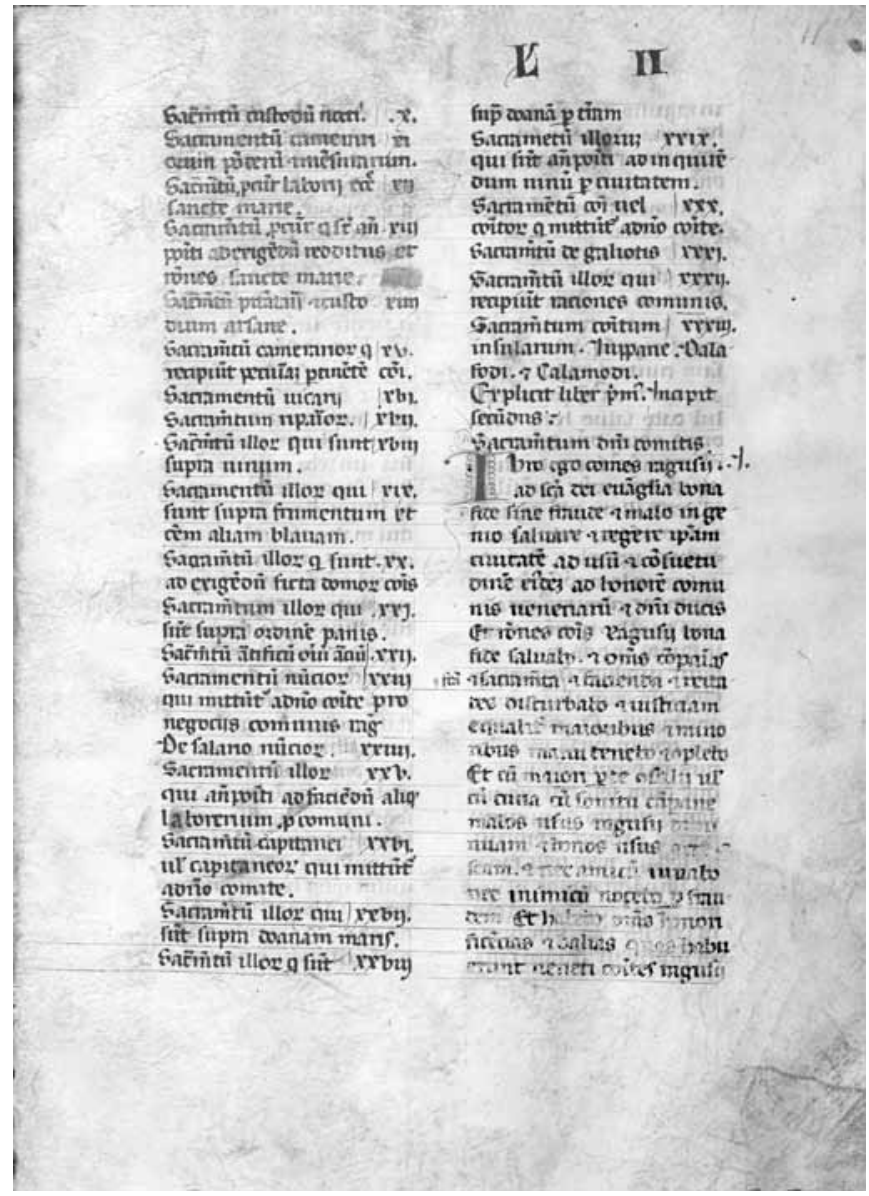

Slika 5. Dubrovački statut, službeni prijepis iz 1342. Državni arhiv u Dubrovniku, ser. 21.1. Manuali pratici del Cancelliere: Leggi e istruzioni, sv. 9b, f. 11 r.

$\overline{123}$ Za dataciju rukopisa vidi Nella LONZA, The Statute of Dubrovnik of 1272: Between Legal Code and Political Symbol, u: The Statute of Dubrovnik of 1272 (ur. Nella Lonza), Dubrovnik: Državni arhiv u Dubrovniku, 2012., 14. 


\section{Kneževi naputak i prisega kao dio dubrovačkog pravnog poretka}

Da je naputak bio za kneza pravno obvezujući akt, vidi se iz dokumenta iz 1300., kada mletačko Veliko vijeće raspravlja je li se Marino Morosini kao dubrovački knez ogriješio o odredbu naputka o izdvajanju za vojsku. ${ }^{124}$ Tom se zgodom precizno citira odredba iz prisege/naputka (commissio comitis Ragusii) da je knez u takvoj zgodi dužan osobno platiti 100 libara jednom godišnje; ${ }^{125}$ pri glasovanju u Velikom vijeću Morosini je oslobođen.

No, naputak je integriran i u dubrovački pravni poredak. To se vidi primjerice iz prijepora između kneza i Velikog vijeća iz 1313. oko toga kome pripada jarbolarina (arboraticum); tražeći rješenje, Vijeće je proučilo odredbu Statuta o tome, ali i izvršilo uvid u knežev naputak (intellecto puncto commissionis domini comitis). ${ }^{126}$

Među tim pravnim aktima uspostavljena je hijerarhija. Kneževa prisega u Dubrovniku morala je poštivati okvir one dane duždu (hec omnia observabo salvo sacramento quod iuravi eidem domino duci Venetie), ${ }_{1}^{127}$ a treća prisega lokalnom crkvenom vrhu nije smjela dovoditi u pitanje gornje dvije prisege (salvo sacramento domini ducis et regiminis civitatis Ragusii et eius consuetudinum). ${ }^{128}$ Iz toga proistječe da je i prisega dubrovačkog kneza duždu vezana uz dubrovački pravni poredak načelom hijerarhije pravnih izvora i da je stoga treba ubrojiti u izvore ,javnog prava" Dubrovnika pod mletačkom vlašću.

\section{Prisega duždu, prisega komuni i politički ideali „dobre vlade”}

Nakon što je razmotren normativni sadržaj ovih akata te njihova tipologija i uloga u pravnom poretku srednjovjekovnog Dubrovnika, potrebno se osvrnuti na baštinu političke misli kojoj pripadaju.

U obje prisege dubrovačkog kneza prepoznaju se odjeci duždeve prisege (promissio) o načelima kojih će se držati u službi, ${ }^{129}$ čija se jezgra, nastala još u

$\overline{124}$ Listine I, br. 284, str. 192.

125 Ibidem i Prisega duždu, [19].

${ }^{126}$ Libri reformationum I, 34. Taj prijepor spominje i Bariša KREKIĆ, Unequal Rivals: Essays on Relations Between Dubrovnik and Venice in the Thirteenth and Fourteenth Centuries, Zagreb - Dubrovnik: Zavod za povijesne znanosti HAZU u Dubrovniku, 2007., 23. Jarbolarinu inače regulira Dubrovački statut, I, 13.

127 Klauzula sadržana u svim citiranim prisegama.

Dubrovački statut, I, 1.

129 Gherardo ORTALLI, Venezia nel secolo di Federico II. Modelli statuali e politica mediterranea, Atti dell'Istituto veneto di scienze, lettere e arti, 157, 1999., 418. 
12. stoljeću, stalno dopunjavala. ${ }^{130}$ Uočljive su sličnosti, primjerice kod zabrane primanja darova i „usluga” i kod obveze pravičnog dijeljenja pravde (equaliter) onima iz višeg i nižeg sloja (maiores et minores). ${ }^{131}$

No, spomenuti elementi iz prisega imaju i značajne dodirne točke s modelom podestatske uprave, koji je zrelo artikulirao ideale „dobre vlade”. Dovoljno je spomenute elemente iz prisege dubrovačkog kneza usporediti s prisegom podestata iz Splitskog statuta, u koju su pretočena mnoga „opća mjesta" iz podestatskih priručnika. ${ }^{132}$ Splitski podestat priseže da neće primati darove od komune ni od pojedinaca, da neće piti ni jesti s građanima i da će na druge načine čuvati svoju nezavisnu poziciju te da će svima dijeliti pravdu pravično (observare equaliter iusticiam), postupajući bona fide, sine fraude, remotis hodio, amore, precio, precibus vel timore aut speciali lucro vel damno. ${ }^{133} \mathrm{U}$ prisezi duždu dubrovački knez slično se obvezuje racionem et iusticiam faciam et fieri faciam omnibus petentibus cum bona fide, ${ }^{134}$ a u prisezi komuni justiciam equaliter majoribus et minoribus manutenebo et complebo... et nec amicum juvabo nec inimicum nocebo per fraudem. ${ }^{135}$ Čak je i družina dubrovačkog kneza slična preporukama iz podestatskih priručnika. ${ }^{136}$

$\overline{130}$ Najstarija sačuvana je Promissio na koju je prisegnuo dužd Enrico Dandolo 1192. Vidi tekst u Le promissioni del doge: 1-4.

Le promissioni del doge, 5, 15-16.

132 Tema podestatske uprave, uloge Tome arhiđakona i refleksa u Splitskom statutu, detaljno je obrađena u radovima Mirjane MATIJEVIĆ SOKOL, Regimen latinorum, 17-32 i „Item iurabunt ipse potestas et sui officiales... facere et obseruare equaliter iusticiam et specialiter ecclesiis, pauperibus, orphanis, uiduis et miserabilibus personis...", u: Statuimus et ordinamus, quod: Sustav moći i mali ljudi na jadranskom prostoru (ur. Robert Matijašić), Poreč: Državni arhiv u Pazinu [itd.], 2005., 268278. Vidi također Jean-Claude MAIRE VIGUEUR, Il podestà che veniva dal mare: Gargano degli Arscindi e l'impianto del sistema podestarile a Spalato (1239), u: Circolazione di uomini e scambi culturali tra città (secoli XII-XIV), Roma: Viella, 2013., 197-220. Djeluje uvjerljivo pretpostavka M. Matijević Sokol o tome da su u Splitski „Percevalov statut” inkorporirani dijelovi starijeg kapitulara načelnika Gargana de Arscindis (Mirjana MATIJEVIĆ SOKOL, Od kapitulara Gargana de Arscindisa do Percevalova statuta, u: Splitski statut iz 1312. godine: povijest i pravo (ur. Željko Radić, Marko Trogrlić, Massimo Meccarelli i Ludwig Steindorff), Split: Knjiženi krug Split, Odsjek za povijest Filozofskoga fakulteta Sveučilišta u Splitu, Pravni fakultet Sveučilišta u Splitu, 2015., 108-110). Citati iz popularnih srednjovjekovnih rasprava (kao što su Pseudoaristotelova Secreta secretorum) vjerojatno su naknadno ubačeni u tekst podestatove prisege u Splitskom statutu, a te se interpolacije mogu po svoj prilici pripisati Percevalu iz Ferma, koji je i uvod Statuta protkao nizom izreka preuzetih iz nekog florilegija. O posuđenicama u uvodu vidi Joško BELAMARIĆ, Proemij Splitskoga statuta, u: Splitski statut iz 1312. godine, 509-526.

Statuta et leges civitatis Spalati (prir. Jaromir Hanel), Monumenta historico-juridica Slavorum Meridionalium, sv. II, Zagreb: JAZU, 1878., II, 16. Slično kod Ivana iz Viterba: Iohannis VITERBENSIS, Liber de regimine civitatum (prir. Gaetano Salvemini), Scripta anecdota glossatorum vel glossatorum aetate composita, Bibliotheca iuridica Medii Aevi, sv. III, Bononiae, 1901., 244-245.

134 Prisega duždu, [3].

135 Dubrovački statut, II, 1.

136 Usp. Prisega duždu, [5] i MATIJEVIĆ SOKOL, Regimen latinorum, 24. 
U starijoj historiografiji na podestatsku se upravu gledalo kao na pojavu isključivo vezanu uz talijanske gradove pod vrhovnom carskom vlašću ili one koji su, poput Splita, prigrlili taj upravni model ne bi li učvrstili svoju zajednicu u odnosu na okolne velikaše i spriječili unutarnje sukobe koji su trajno prijetili. Činilo se da gradovi pod mletačkom vlašću - koji nisu pozivali nezavisnog stranca nego su primali poglavara upućenog odozgo - nema s tom tradicijom ništa zajedničko. Novija istraživanja potvrdila su međutim da je mletačka kultura upravljanja bila itekako nadahnuta nekima od istih političkih načela. Osim preko popularne literature o podestatskoj upravi i priručnika o ars dictaminis, ${ }^{137}$ utjecaj se širio i time što su mletački plemići ponekad bili birani za podestate drugih talijanskih gradova prenoseći tamošnja iskustva u svoj zavičaj i na službe u gradovima u koje su bili upućivani. Osim toga, notari u službi mletačkih kneževa često su još pri školovanju upili ideale podestatske uprave kao svoju „intelektualnu popudbinu”. ${ }^{138}$

Zahvaljujući tome, mletački su se ideali „dobre vlade” napajali iz iste baštine predhumanističke političke misli kao talijanske komune s podestatskom upravom, premda ne toliko snažno i očito. U toj su baštini naprimjer razrađene Ciceronove misli o tome da onaj koji je na čelu neke zajednice ne smije imati pred očima vlastitu korist nego zajedničko dobro i da treba skrbiti za dobro svih, a ne samo dijela društva. ${ }^{139}$ Samo se za te vrline poglavara naime smatralo da će trajno jamčiti mir i unutarnju slogu kao najviše političke vrijednosti. ${ }^{140}$ Daleki odjek tih načela prepoznaje se i u nekim elementima prisega dubrovačkog kneza, kojima se željelo ojačati njegovu nepristranost i potisnuti trku za vlastitim probitcima.

Zaključno se može istaknuti da su prisege i naputak po svojoj prirodi ponajprije konkretni pravni izvori koji daju okvir službi dubrovačkog kneza. No, itekako je važan i njihov „politički kod”, u koji je ugrađena mletačka inačica ideala „,dobre vlade", koncepta koji je obilježio misao i praksu razvijenih talijanskih komuna.

$\overline{137}$ O utjecaju ta dva žanra na političku misao predhumanističkog razdoblja vidi Quentin SKINNER, Visions of Politics, sv. II - Renaissance Virtues, Cambridge [etc.]: Cambridge University Press, 4. izadnje, 2007., 18-28.

138 Vidi Elisabeth CROUZET-PAVAN, Venise et le monde communal: recherches sur les podestats vénitiens, u: I podestà dell'Italia comunale, sv. I - Reclutamento e circolazione degli ufficiali forestieri (fine XII sec. - metà XIV sec. (ur. Jean-Claude Maire Vigeur), Roma: École françise de Rome, 2000., 259-286. Općenito o kulturnoj baštini podestatske uprave vidi Enrico ARTIFONI, I podestà professionali e la fondazione retorica della politica comunale, Quaderni storici, 21, 63, 1986., 687-719 i druge radove istog autora.

SKINNER, Visions of Politics, 24-25. O temi „općeg dobra” u dubrovačkoj političkoj tradiciji vidi Nella LONZA, Obliti privatorum publica curate: preci i srodnici jedne političke maksime, Anali Zavoda za povijesne znanosti HAZU u Dubrovniku, 44, 2006., 25-46. 


\section{Prilog. Prisega dubrovačkog kneza duždu.}

Archivio di Stato di Venezia, Collegio, Formulari di commissioni, reg. 1, f. 117r$118 \mathrm{v}$, integirano s tekstom iz drugih prisega iz istoga sveska, kad se na njih upućuje. U izvorniku su gl. 1-20 pisane u kontinuitetu. Radi lakšeg praćenja glave su numerirane. $U$ bilješke su unesene razlike $u$ čitanju u odnosu na izdanje: Le commissioni ducali ai rettori d'Istria e Dalmazia (1289-1361) (prir. Alessandra Rizzi), Roma: Viella, 2015., 242-247. Rukopisi : prvi pisar 1-23; drugi pisar 24-25; treći pisar: 26-27; četvrti pisar 28; peti pisar osnovni tekst 29; šesti pisar 30 i osnovni tekst 3132; sedmi pisar 33; osmi pisar 34 i osnovni tekst 35-37; deveti pisar 38; deseti pisar osnovni tekst 39 i čitav 40; do kraja svaki unos drugom rukom.

[1] (F. 117r) Iuro ad evangelia Sancti ${ }^{141}$ Dei quod fidelis ero domino duci Veneciarum et usque dum ero comes Ragusii tractabo et operabo ${ }^{142}$ proficuum Veneciarum et salvacionem Ragusii cum honore et bono Veneciarum.

[2] Et stabo in regimine dicte civitatis a die primo quo intravero Ragusium usque ad duos annos completos, ita quod Venecias non veniam nec inde recedam usque ad completum duorum annorum predictorum, nisi hoc facerem et fieri faciam de licencia domini ducis et maioris partis sui consilii.

[3] Racionem et iusticiam faciam omnibus petentibus cum bona fide.

[4] Habere quidem (in margine: debeo) integre dacium et raciones comitatus ut consueti sunt habere comites dicte civitatis.

[5] Et habere et tenere debeo meis expensis duos decentes socios Venetos quibus dabo libras $L$ denariorum Venetorum vel inde supra pro quolibet omni anno (in margine: et vestes videlicet duas robas decentes pro quolibet omni anno), et unum notarium, sive clericum sive laicum, et duodecim servientes qui non sint de Dalmacia, ex quibus octo sint armati armis fereis, et tres equos.

[6] Nec mecum tenebo aliquem notarium vel socium aut alium in familia qui faciat et exerceat mercationem per aliqum modum vel ingenium.

[7] Et negociaciones non exercebo per me nec per alios donec stetero in dicto regimine, excepto quod possum salarium meum investire semel in anno et non plus.

[8] Et non permittam socios meos nec notarium nec servientes nec aliquem alium de familia mea exercere negociationes in dicta terra.

[9] Item attendam et observabo omnia et singula qua continetur in pacto facto inter Ragusium et Venetias bona fide.

\footnotetext{
$\overline{141}$ Le commissioni ducali, 242: sancta.

142 Završetak riječi je nejasan. Čini se da ima pasivnu formu „operabor”, koja se ne uklapa u sintaksu rečenice.
} 
[10] Item observabo et observari faciam capitula que fuerint scripta et determinata tempore regiminis nobilis viri Iohannis Teupuli comitis Ragusii. Et in omnibus aliis maledictis et maleficiis habere debeo liberum arbitrium ad puniendum et condempnandum ipsa maledicta et maleficia sicut mee discrecioni videbitur.

[11] Bona quoque Venetorum qui ab intestato apud Ragusium decesserint studiosus ero intromittere et salvare et Venecias mittere secundum mandatum domini ducis et sui consilii.

[12] Preterea studiosus ero facere presentari omnes litteras de bina contestacione que mihi porecte fuerint et quod inde fiat breviarium ad expensas illius qui ipsas voluerit presentare.

[13] Et ero astrictus de proficuo et honore Veneciarum eundo, stando et redeundo per XV dies post meum redditum in Venecias, infra quos omnia que de facto Ragusii sciero, que credidero esse dicenda et fore utilia pro proficuo et honore Veneciarum et salvatione dicte terre, dicam et notificabo domino duci et suo consilio tam si inde interogatus fuero quam non.

[14] Amicum non iuvabo nec inimico nocebo per fraudem.

[15] Et servicium vel donum non tollam nec tolli faciam propter hoc per totum tempus huius regiminis nec per medium annum postquam de regimine exibo per me vel per alium ullo modo, in pena dupli de eo quod per me aceptum erit, et si tultum sciero, faciam illud reddi si potero.

[16] Nullum itaque donum sive presens acipiam nec accipi faciam ab aliqua persona Ragusii nec aliarum terrarum Sclavonie nec Dalmacie aliquo modo vel ingenio, et si aceptum scivero, faciam illud reddi quam cito potero.

[17] Tamen licitum est mihi ea que dari solet et debent ( $f .117 v)$ pro regaliis dicte terre recipere.

[18] Sciendum est quod dimittere debeo personam loco mei in Veneciis que faciat omnia imprestita et avetatica ${ }^{143}$ pro me que facient alii homines Veneciarum in predictis duobus annis.

[19] Et si contingerit exercitum per particionem fieri, solvam vel solvi faciam pro persona libras $C$ semel in anno.

[20] Nec aliquis filius meus divisus vel indivisus non debet Ragusium ad mercatum venire nec ibidem negociaciones exercere infra dictum tempus duorum annorum.

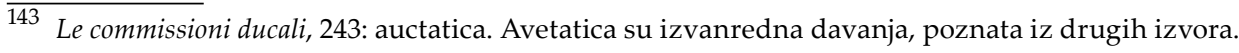


[21] Preterea studiosus ero et dabo operam quod per comune et homines Ragusii solvatur regaliam, ${ }^{144}$ quam solvere debent et tenentur comune et homines Ragusii domino duci et comuni Veneciarum termino constituto. ${ }^{145}$

[22] Item non possum nec debeo aliquo modo vel ingenio absolvere aliquas condempnationes in pecuniis ${ }^{146}$ factas per aliquem vel aliquos predecessorum meorum, nec de ipsis ${ }^{147}$ condempnationibus vel earum occasione facere seu fieri facere aliquam compensationem, donum seu graciam aut ullam provisionem nisi cum voluntate domini ducis et sui consilii de $\mathrm{XL}$ vel de maiori consilio, pocius illas condempnationes ad meum posse excuttere teneor seu excuti facere si non sunt excusse. Item observabo formam consilii in quo inter cetera continetur sic. Et sicut non possum absolvere condempnationes precessorum meorum in pecuniis ${ }^{148}$ factas, sic non possum absolvere illas que facte sunt vel fient de cetero in persona et rebus occasione homicidii, furti et tradimenti aliquo modo vel ingenio.

[23] Item non possum nec debeo per me aut per meum vicarium vel per alios impedire aut facere impediri aliquam personam undecumque sit que velit venire Venecias cum frumento vel alia blava, nec ipsum frumentum vel blavam, pocius teneor ei dare auxilium, consilium et favorem cito cum ipsis frumento et blava Venecias veniendi. Et si contrafecero, cadam in pena librarum $C$ pro qualibet vice, quam penam infra unum mensem postquam ab hoc meo regimine Venecias rediero camerariis comunis sub pena tantumdem solvere teneor, et advocatores comunis penas ipsas excuttere debeant, et nichilominus id quod impediero Venecias mittere teneor per sacramentum.

[24] Item observabo formam consiliorum infrasciptorum que talis est. MCCLXXXXII, die quintodecimo mensis novembris, VI indictione. Capta fuit pars in maiori consilio quod nulla persona audeat ludere inter diem et noctem in aliquo loco in episcopatu Veneciarum et Torcelli a soldis $\mathrm{X}$ grossorum supra ad aliquem ludum preter quam ad scachos et tabulas, sub pena librarum XXV pro quolibet, tam illorum qui ludent, quam illius qui permitteret ludi in domo sua. Et nichilominus ille qui lucratus fuerit teneatur restituere totum id quod lucratus erit ei qui perdiderit. Et iniungatur illis de nocte quod debeant excuttere dictas penas et facere fieri dictam resititucionem ei qui perdiderit infra tertium

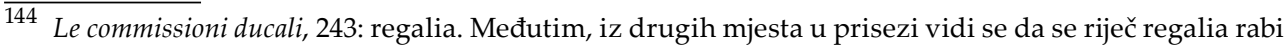
kao da je u jednini ženskoga roda.

145 Le commissioni ducali, 243: costituto.

146 Le commissioni ducali, 243: pecunia.

147 Le commissioni ducali, 243: ispis.

148 Le commissioni ducali, 243: pecunia.
} 
diem, et propter hoc habeant tercium, et tercium accusator, si per eius accusationem veritas cognoscetur, et reliquum sit comunis. Et in hoc non intelligatur galeoti nec publici baraterii a columpnis. Et si consilium est contra, sit revocatum quantum in hoc. Item eodem millesimo, die XV januarii capta fuit pars in maiori consilio quod consilium per quod prohibetur ne ludatur ultra soldos $\mathrm{X}$ grossorum iniungatur omnibus duchis, baiulis, comitibus et omnibus rectoribus qui sunt et erunt per dominum ducem et comune Veneciarum, ut ipsum faciant publicari et observari per sua regimina in omnibus sicut continet, et excepto quod si Venetus ludet cum forinseco, non teneatur facere restituere Venetum id quod lucratus fuerit forinseco, in quo casu cadat Venetus in penam librarum $L$, medietas cuius pene deveniat in accusatorem si per eius accusationem veritas cognosceretur et alia $(f$. $118 r$ ) medietas deveniat in nostrum comune. Et si aliquis lusisset extra Venecias in quocumque loco nec esset punitus per istum modum, iniungatur illi de nocte quod debeant excuttere dictas penas et facere fieri dictas restituciones postquam id sciverint vel eis fuerint accusati, sicut faciunt ab illis qui ludunt in Veneciis. Et si aliquis luserit in aliquo navigio contra dictum ordinamentum, cadat in dictam penam, et teneantur omnes rectores ad quorum noticiam primo pervenerit ${ }^{149} \mathrm{fa}-$ cere fieri dictas restituciones et excuttere dictas penas. Et si dicte restituciones et pene non fuerint facte et excusse per rectores, ut dictum est, debeant exigi et fieri per dominos de nocte postquam id sciverunt sicut faciunt et exigunt ab illis qui ludunt in Veneciis. (Cassum, in margine: vacat).

[25] Item cum comune Ragusii teneatur et debat dare domino duci libras VII et soldos XII denariorum Venetorum grossorum omni anno in festo omnium sanctorum pro regalia, ego procurabo et faciam ita quod dicta regalia dabitur ei in Veneciis in dicto termino omni occasione remota.

[26] Item quia multa mala fuerunt ${ }^{150}$ per uxores, filios et socios rectorum qui vadunt in regimina domini ducis et comunis Veneciarum, capta fuit pas quod addatur in commissionibus omnium rectorum qui decetero ibunt per dominum ducem et comune Veneciarum quod si eorum uxores vel heredes, tam masculus quam femina, vel socius, fecerint aliquid quod sit vetitum ipsi rectori per suam comissionem, et illa uxor sua vel filii vel socius fuerit acusatus domino duci vel advocatoribus comunis, quod ille rector sit responsator et pagator de omni eo quod advocatores convincerent ad illud consilium in quo ipsi volent placitare. Et hoc addatur in capitulare ${ }^{151}$ advocatorum comunis quod ita debeant placiare ipsum rectorem pro uxore et heredibus et socio sicut placitarent ipsum rectorem. Et

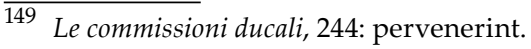

150

Le commissioni ducali, 244: fiunt.

151 Le commissioni ducali, 245: capitulari.
} 
non intelligatur heres qui non habuerit ultra XVI annos. E hoc non possit revocari nisi per $\mathrm{V}$ consiliarios, $\mathrm{XXX}$ de $\mathrm{XL}$ et duas partes maioris consilii. Et advocatores comunis habeant talem partem de omni eo quod ipse fuerit propterea condempnatus, qualem habent de aliis quos placitant.

[27] Preterea ab omnibus nostris fidelibus qui portarent ad terras Saracenorum soldano subiectas equos, arma, ferrum, lignamen vel alia cum quibus Saraceni possent impugnare Christianos, accipies totum illud quod portarent vel valorem ipsius. Et insuper si quis mitteret predicta vel aliquid de predictis vel in cambium faceret vel fieri faceret aut imprestitum cum aliqua persona que iret ad predicta loca per se vel per alium ullo modo vel ingenio vel eciam portaret vel portari faceret Mamuluchos, cadat in similem penam. Et si quis contrafaceret qui esset de maiori consilio, sit extra omne consilium et beneficium comunis Veneciarum in perpetuum. Et si non esset de maiori consilio, nunquam possit esse de ipso vel eligi. Et si aliquis marinarius esset obligatus ad tale viagium, nulla sit eius obligatio, sed sit absolutus de ipsa, et si contrafaceret, cadat in penam ${ }^{152}$ librarum L pro quolibet et qualibet vice, et patronus et nauclerius in libris C. Et si in partibus tui regiminis caricarentur predicta vel aliquod predictorum, debeas decipere pleçariam quod ipsa non portabunt ad loca predicta. Et si aliquis in Veneciis vel in Segna vel alibi caricaret lignamen vel ferrum pro ire extra Culfum ad aliquam terram, teneatur facere venire infra unum annum litteram a recthore (!) illius loci quod predicta illuc portaverint vel aliam probam facere vel fieri facere, quod dominus dux et suum consilium habeat contentari, sub pena quarti. Et si aliquis caderet ad aliquam predictarum penarum et non invenirentur de suis bonis, stet in carcere donec solverit dictam penam etsi consilium est contra etc. Et provisores nostri comunis dictas penas excutere teneantur et carcerari facere illos quorum bona non invenirentur. Et qui acusaverit, si per eius acusationem veritas habebitur, habeat medietatem ipsius pene et teneatur de credencia.

[28] Item non possum recipere nec recipi facere aliquo modo vel ingenio aliquod inprestitum ab aliquo Raguseo nec ab aliquo Veneto qui utatur vel uti faciat Ragusio $^{153}$ nec ab aliquo pro eis.

[29] (F. 117v, in margine inferiori) Item observabo formam consilii capti in $\mathrm{M}^{\circ} \mathrm{C}-$ CLXXXXVII, mensis marcii, continentis quod comes Ragusii qui nunc et decetero eligetur debeat esse contentus quod de attagi, que hactenus veniebant in comitem, habere debeat libras VIII grossorum in anno si placebit comuni Ragusii et ipse ${ }^{154}$ attagi deveniant in comuni Ragusii. Et si comune Ragusii non esset inde contentum, remaneant in statu in quo sunt modo.

\footnotetext{
152 Le commissioni ducali, 245: pena.

153 Le commissioni ducali, 245: Ragusii.

154 Le commissioni ducali, 244: ipsi.
} 
[30] Item teneris ante quam de regimine isto recedas et debes facere rationem sucessori tuo de omnibus que dimitteris in comuni, tam in denariis quam in aliis rebus omnibus. ${ }^{155}$ Et predictus sucessor vel successores teneantur audire et recipere dictam rationem et ipsam per suas litteras domino duci significare per precessorem suum per singulum. ${ }^{156}$

[31] Item observabo consilium loquens quod rectores non compellant piscatores sibi vendere suos pisces, quod invenies in comissione Iustinopolis hoc signo signatum $\mathrm{X}_{1}{ }^{157}$ (F. 71r) Item observabo formam infrascripti consilii capti in $\mathrm{M}^{\circ} \mathrm{CCCXVIII}$, indictione $2^{\mathrm{a}}$, die XIII februarii in maiori consilio, continens quod iniungatur in commissionibus omnium ${ }^{158}$ rectorum qui mittuntur per comune Veneciarum, quod decetero in partibus sui regiminis non compellant nec compelli faciant per se vel alium aliquem piscatorem vel venditores piscium quod sibi vendat pisces, nec conducat eos ad domum suam ipsorum rectorum, nec paciantur quod aliquis de sua familia vel aliis faciat eis violenciam aliquam vel gravamen, sed permittant quoslibet vendere libere et sine impedimento in locis publice solitis sicut voluerunt suos pisces. Et si consilium vel commissio vel capitulare est contra etc.

[32] Et non possum recedere ab hoc regimine nisi successor meus illuc applicuerit $^{159}$ vel nisi licentiam habuero a domino duce ${ }^{160}$ habendo tamen ${ }^{161}$ salarium per ratam de quanto stetero usque ad adventum successoris.

[33] Item observabo consilium de armis quod est in carta $14^{162}$ signatum sic $\mathrm{X}_{2}$ in capitulario potestatis Iustinopolis. (F. 71r) Item observabo quantum ad me spectat consilium captum in $\mathrm{M}^{\circ} \mathrm{III}^{\mathrm{C}} \mathrm{XVIIII}{ }^{\circ}$, die XIIII februarii, continens quod iniungatur in commissionibus omnium rectorum comunis Veneciarum quod in eorum recessu a regimine consignent eorum successoribus per singulum omnia arma comunis nostri que erunt in suo regimine, que dicti successores faciant notari in quaterno sicut fuerint consignata, et nichilominus per suas litteras rescribant domino duci ipsa arma, et ad conservandum ipsa ne devastentur fuerint studiosi. Et si consilium etc. ${ }^{163}$

\footnotetext{
155 Pisar se očito zabunio pa počeo prepisivati u trećem licu jednine, naknadno preradivši tekst u prvo lice jednine.

156 Zbog oštećenja pergamene, transkripcija riječi uz desni rub preuzeta je iz Le commissioni ducali, 245.

157 Umjesto iscrtanoga znaka, uvedena je oznaka X s pratećim brojem.

158 Izostavljena riječ u Le commissioni ducali, 115.

159 Le commissioni ducali, 246: applicaverit.

160 Le commissioni ducali, 246: duci.

161 Nečitko mjesto, preuzeto iz Le commissioni ducali: 246.

162 Podudara se sa starim brojem folija na dnu stranice.

163 Posljednje riječi u izvorniku nečitke, preuzete iz Le commissioni ducali, 114.
} 
[34] Item quod multi rectores faciunt expensas per consuetudinem etc., carta 6. $\mathrm{X}_{3}$. (Cassum). (F. 71r) Item quia multi rectores faciebant expensas per consuetudinem quam dicebant servatam per suos precessores, captum fuit et ordinatum fuit quod officiales rationum ${ }^{164}$ non recipiant aliquas expensas rectorum et ambaxatorum de quibus non habeant libertatem in suis commissionibus, nec in collegio possint recipi nisi usque ad summam librarum XX parvorum, et sic addatur in commissionibus (...).

[35] (F. 118v) Millesimo CCC ${ }^{\circ} \mathrm{VIII}^{\circ}$, die VIII augusti. Cum insula de Lagusta sit supposita dominio comitum nostrorum de Ragusio et ipsi habeant certas iurisdictiones in ipsa, videlicet de mulieribus que inveniuntur fornicari, de decimis omnium bladorum, de vino et capredis, de furtis que fiunt in insula, de sceleris et coniglis que nascuntur supra, ${ }^{165}$ de percussionibus et effusione sanguinis et de certis aliis iurisditionibus, et quia dicta insula est multum gravata et deducta ad inopiam propter gravamina que sibi fiunt per vicecomites qui illuc mittuntur, illi de ipsa insula suplicarunt nobis quod digneremur ${ }^{166}$ super eorum gravaminibus providere. Capta fuit pars quod comites de Ragusio propter supradictas iurisditiones habeant annuatim ab hominibus de Lagusta libras VIII grossorum et soldos $\mathrm{XV}$ grossorum pro falconibus, et dicte iurisditiones remaneant in comuni de Lagusta, et hoc consulunt homines ${ }^{167}$ de Lagusta qui fuerunt per tempora. Et teneantur dicti comites mittere illuc suum vicarium qui habeat yperpera quinquaginta annuatim pro salario ab illis de Lagusta et comittatur sibi quod bene se habeat erga illos de Lagusta et eos regat bene et honeste et hec durent ad beneplacitum domini ducis.

[36] Vero ${ }^{168}$ qui fuerit vicarius ibi duobus annis non possit esse magis usque ad duos alios annos sed sit ipse socius ad conditionem aliorum sociorum et cancellariorum secundum formam consilii. Et hoc captum fuit in consilio rogatorum 1313, indictione 6, die II ianuarii. ${ }^{169}$

[37] Item observabo consilium loquens de magistro Jacobo quondam notario in Insula etc., ut in Iustinopoli hoc signo $\mathrm{X}_{4}$. (F. 71r) Item observabo formam huius infrascripti consilii capti in consilio de $\mathrm{XL}$ in $\mathrm{M}^{\circ} \mathrm{CCC}{ }^{\circ} \mathrm{XXV}$, die $\mathrm{XV}^{\circ}$ iulii, VIII indictione, videlicet quod committatur nostris rectoribus et officialibus quod magistrum Iacobum qui, existens notarius in Insula cum ser Marco Maurocoe-

\footnotetext{
164 Le commissioni ducali, 115: nostri.

165 Le commissioni ducali, 246: sicut.

166 Le commissioni ducali, 243: dignaremus.

167 Naknadno dopisano: comites, što je vjerojatno ispravka.

168 Le commissioni ducali, 246: verum.

169 Posljednje riječi u izvorniku nečitke, preuzeto iz Le commissioni ducali, 246.
} 
no ibidem potestate, commisit falsitatem in quibusdam quaternis sententiarum et in aliis, non debeant tenere nec recipere pro notario. (Cassum).

[38] Item est sciendum quod in MCCLXV, die XIIII exeunte mensis maii capta fuit pars, ut in commissione Iustinopolis continetur sub hoc signo $\mathrm{X}_{5}$. (F. 71r) Item sciendum est quod in MCCLXV, die XIIII exeunte mensis maii capta fuit pars in maiori consilio quod quicumque decetero ibit seu modo est in regimine, ambaxariis, capitanariis vel aliquo alio officio pro comuni Veneciarum, et convictus fuerit per dominum ducem et eius consilium ${ }^{170}$ de $\mathrm{XL}$, vel per $\mathrm{XL}$ cum domino duce et ius consilio, vel per maius consilium, aut pro placitare advocatorum comunis, quod furatus fuerit de bonis et havere comunis vel aliter ab aliis contra suam commissionem et suum capitularem acceperit ${ }^{171}$ libras L illi de extra et libras XXV illi de intus, debeant solvere quod sententiatum fuerit in dupplum usque ad VIII dies tunc proximos. Et si non solverit capitale et penam duppli, non possit habere officium in Veneciis nec extra, nec esse de maiori consilio usque ad $\mathrm{V}$ annos proximos, et nichilominus dominus dux et consiliarii teneanur exigere et capitale et dupplum ab eis. Et quicumque donaverit vel dederit alicui de bonis comunis contra suum capitularem vel commissionem, debeant (!) restaurare de suo proprio infra VIII dies tantum quantum dederit. Et si non solverit, cadant (!) in dictas penas duppli et privationis officiorum et maioris consilii ut est dictum. Et preterea si illi de ratione dixerint quod de predictis (...) habeant de havere comunis libras XXV illi de extra vel inde supra, precipiant quod ${ }^{172}$ solvant, et libras $X$ illi de intus vel inde supra (...) solvant usque ad VIII dies, et si non solverint cadant in pena duppli, et non possint usque ad (...) habere officium comunis (nec) esse de maiori consilio, salvo in omnibus officio advocatorum comunis. Et hec omnia debeant addi in commissiones ${ }^{173}$ rectorum secundum quod captum est in maiori consilio MCCCXXX, die X iulii. (Cassum).

[39] Item observabo formam consilii capti in consilio de $X L$, ut in commissione capitanei Paysanatici continetur sub hoc signo $X_{6}$. (F. 65r) Item observabo formam consilii capti in consilio de XL in MCCCXXXVIII, ${ }^{174}$ indictione sexta, die ultimo iullii, que talis est. Cum malefitium perpetratum ${ }^{175}$ per Marcum Val-

\footnotetext{
170 Le commissioni ducali, 116: consiliarios.

171 Le commissioni ducali, 116: acceperint.

172 Le commissioni ducali, 116: quod eis.

173 Le commissioni ducali, 116: in commissionibus.

174 Le commissioni ducali, 246: CCCVIII.

175 Le commissioni ducali, 101: prope actum.
} 
laresso, filium ${ }^{176}$ ser Bellini, in personam Nicoleti Maripetro eius cugnati, ${ }^{177}$ existentibus ipsis circumstantiis mattando et occidendo eum cum una secure et prohiciendo ${ }^{178}$ eum in unam latrinam, ${ }^{179}$ sit orribile et crudelissimum, capta fuit pars ut de ipso facto fiat quod spectat pro honore dominii et quod requirunt iustitia et orribilitas maleficii, quod gridetur ${ }^{180}$ publice, quod quicumque dederit ipsum Marcum in manibus et fortia dominii vel manifestaverit dominio taliter quod per eius accusationem vel manifestationem habere possit, habeat ${ }^{181}$ a nostro ${ }^{182}$ comuni libras CC grossorum. Et si quis ${ }^{183}$ dederit eum mortuum ${ }^{184}$ vel interfectum, probando ita esse, habeat a nostro comuni libras $\mathrm{C}$ grossorum. Et scribatur omnibus nostris rectoribus et addatur in eorum commissionibus et capitaneorum quod dent operam de capiendo dictum Marcum, si inventus fuerit in suis rationibus, et de mittendo celeriter ${ }^{185}$ nobis sub bona custodia et in ferris. Et quod dictum bannum fatiant notum et publicum ${ }^{186}$ semel ad minus tempore suorum regiminum (...), ${ }^{187}$ intelligendo quod tam rectores quam omnes de sua familia et habentes salarium ${ }^{188}$ vel soldum ${ }^{189}$ comunis quam omnes alii quicumque $^{190}$ sint, si eum dederunt ${ }^{191}$ mortuum $^{192}$ vel vivum, habeant dictam pecuniam in casibus antedictis.

[40] Item observabo formam consilii capti in $\mathrm{M}^{\circ} \mathrm{CCC}^{\circ} \mathrm{XXXVIII}{ }^{\circ}$, indictione $\mathrm{VII}^{\mathrm{a}}$, die primo octubris in consilio rogatorum, cuius tenor per omnia talis est, quod comes Ragusii presens et alii qui erunt decetero teneantur in eorum recessu a dicto regimento facere quod sui notarii omnes scripturas quas suo tempore fecerunt dare et deponere debeant in cancellaria comunis Ragusii ut omni tem-

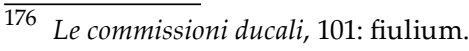

177 Le commissioni ducali, 101: cugnatum.

178 Le commissioni ducali, 101: prohiciendo.

179 Le commissioni ducali, 101: una [...].

180 Le commissioni ducali, 101: audeant.

181 Le commissioni ducali, 102: et habeat.

182 Le commissioni ducali, 102: nostri.

183 Le commissioni ducali, 102: siquis.

184 Le commissioni ducali, 102: mortum.

185 Le commissioni ducali, 102: esset.

186 Le commissioni ducali, 102: publicari.

187 Le commissioni ducali, 102: que suis parebit.

188 Le commissioni ducali, 102: habitantes palatium.

189 Le commissioni ducali, 102: soldati.

190 Le commissioni ducali, 102: quocumque.

191 Le commissioni ducali, 102: dedunt.

192 Le commissioni ducali, 102: mortum.
} 
pore scripture tam civium quam regiminis ${ }^{193}$ habere possint sicut fuerit oportunum.

[41] Item observabo formam duorum consiliorum, ut in commissione potestatis Valis continetur hoc signo $X_{7}$ (F. 66r) Item observabo quod qui fuerit notarius, cancellarius, iudex vel socius mei precessoris seu in aliquo officio, non possit esse in aliquo officio in dicto regimine usque ad duos annos post complementum rectoris cum quo fuerit.

[42] (F. 66r) Item observabo consilium continens quod si aliquis habens cancellariam, scribaniam vel postam pedestrem vel equestrem vel aliam postam, capitanariam barceriorum seu aliud officium vel consilium in aliqua terra nobis subiecta, per pecuniam vel aliam provissionem fecerit vel tractaverit taliter quod aliquod eorum sibi detur vel in alium transferatur, ipsa dacio vel translatio non valeat nec teneat, sed de presenti revocatur, et loco ipsius alius per ducale dominium subrogetur, et nichilominus totum quod dedisset vel habuisset vel alius pro eo occasione predicta, restituatur in totum ei qui dederit. Et insuper incurrat ille qui tractaverit et fecerit in penam ${ }^{194}$ medietatis eius quod habuerit vel habere debuerit vel alius pro eo, que penna (!) exigatur per advocatores comunis, de qua habeant medietatem et alia sit comunis. Et illi qui darent vel promitterent cadant de medietate eius quod dederint vel promisserint pro penna que dividatur ut supra. Et si accusator fuerit in predictis, dividatur pena per tercium. Et iniungatur nostris rectoribus quod predicta observent et faciant observari et contrafacientes denotent advocatoribus comunis.

[43] Item observabis formam consilii capti in rogatis, ut in commissione Vallis continetur sub hoc signo $X_{8}$. (F. 66r) Preterea cum sit quoddam consilium quod nullum habere subtile possit adduci Venecias contra ordines, videlicet cum navigio disarmato, et per ipsum nostra intencio non impleatur ad plenum, quia adducentes illud obtinent gratiam ${ }^{195}$ largo modo et non verentur continue adducere de havere predicto in dannum tocius terre, ideo capta fuit pars in consilio rogatorum quod nullum havere subtile exceptis auro, perlis ${ }^{196}$ et eo quod inteligatur ${ }^{197}$ havere capselle, ullo modo conduci Venecias possit cum navigio disarmato vel contra ordines, sub pena perdendi totum quod contra hoc adduceretur, sine ulla remissione. Et preterea comittimus tibi quod in omnibus navigiis disarmatis que ad partes tui regiminis declinarent, dilligenter facies inquiri et circhari si in eis aliquid adduceretur de dicto havere subtili, et si inveneris aliquid contra predicta,

193 Le commissioni ducali: 107: forensium.
194 Le commissioni ducali, 107: pena.
195 Le commissioni ducali, 107: guerram.
196 Le commissioni ducali, 107: perllis.
197 Le commissioni ducali, 107: intelligeretur. 
illud accipies et divides per tercium, videlicet tercium erit tuum, tercium dabis acusatori si inde fuerit et tenebis eum in credencia, et tercium mittes nostris ${ }^{198}$ camerariis comunis, quibus commissimus quod illud in Rivoalto plubice (!) faciant incantari et vendi cum licencia nostra, et si accusator non esset, duas partes eius quod inveneris mittes camerariis comunis. ${ }^{199} \mathrm{Et}$ de predictis non potest fieri gratia, donum, suspensio, provisio vel recompensacio aut revocacio sub pena librarum M pro quolibet consiliario, capite de XL vel alio qui possit ponere partem, in quam penam incurrant omnes qui consentirent poni partem predictam.

[44] Item observabis partem captam in consilio rogatorum sub millesimo $\mathrm{CCCL}^{\circ}$, indictione IIII, die III ianuarii, ut in commissione comitis Tragurii continetur sub hoc signo $\mathrm{X}_{9}$. (F. 85v) Millesimo $\mathrm{CCCC}^{\circ} \mathrm{L}$, indictione $\mathrm{IIII}^{\mathrm{a}}$, die $\mathrm{III}^{\circ}$ ianuarii, in consilio rogatorum et XL capta fuit pars infrascripti tenoris. Preterea committatur rectoribus nostris Sclavonie quod teneantur et debeant apponere diligentem curam et custodiam ne sal extrahatur de terris suis pro eundo contra ordines nostros. Et ob hoc quando aliquis voluerit extrahere salem de terris suis, debeant (!) accipere pleçariam quod non ibunt contra ordines nostros et quod facient venire contraliteras a rectoribus locorum ubi detulerint dictum salem, sub pena librarum XXV. Et si aliquid extractum fuerit de dictis terris et iverint contra banna nostra, debeant dicti rectores notificare officialibus nostris de catavere, intromictendo nichilominus personas et bona tam principalium quam fideiussorum illorum qui fecerant contrabanna usque ad integram satisfactionem eius quod commiserint. Et dicti rectores, inventores et accusatores habeant illam partem quam in similibus casibus habent ${ }^{200}$ rectores et custodes nostri a Grado usque ad Caput Aggeris. Et insuper commictatur rectoribus Sclavonie predictis quod faciant et ordinent sub illis penis et modis qui sibi videbuntur, quod illi qui levant vel levari faciunt salem in terris et regiminibus suis teneantur et debeant sibi dare in scriptis totam quantitatem salis levati et de ipso non vendere sine licentia rectorum nostrorum.

[45] Item observabis partem captam, ut in commissione Iustinopolis continetur sub hoc signo $X_{10}$. Ceterum cum Zaninus Vidal condam ser Clementis Sancti Raphaelis enormia delicta commissit in civitate nostra, captum fuit in nostris consiliis minori et $\mathrm{XL}, 1353$ mensis novembris quod sit banitus de omnibus terris et locis subiectis nostro dominio. Et propterea tibi committimus quod, si in partibus tui regiminis reperiri contingerit, eum capi facias et ad nos sub fida custodia in catenis fereis mittas Venecias ut de eo fieri possit iusticia ordinata. ${ }^{201}$

\footnotetext{
$\overline{198}$ Le commissioni ducali, 107: nostri.

199 Le commissioni ducali, 107: civitatis.

200 Le commissioni ducali, 159: habeant.

201 List iz registra je izbugljen. Uz pomoć sljedećeg sveska tekst je rekonstruiran u Le commissioni ducali, 130, odakle je ovdje preuzet.
} 
[46] Item observabis partem captam in maiori consilio, ut in commissione capitanei Paysenatici, continetur sub hoc signo $X_{11}$ (F. 67v) Et non potes sub debito sacramenti per totum tempus tui regiminis et per unum annum post contrahere vel contrahi facere matrimonium nec impetrare seu impetrari facere aliquam prebendam vel beneficium in locis tui regiminis pro te, filiis vel aliis, nec procurare aut ${ }^{202}$ tractare quod hoc faciat ${ }^{203}$ pro te vel aliis ullo modo. (In margine: 5 februarii, in maiori consilio).

[47] Item observabis partem contentam in commissione capitanei Paysenatici sub hoc signo $X_{12}$. (F. 67v) 1355, die 25 septembris. Scire debes quod propter horrendum excessum commissum in personam Hermellini de Musto, civis nostri, ex tractati Zanini Superacio (!) campsoris Sancti Severi, qui dyabolico spiritu instigatus $^{204}$ ipsum assassinari et occidi nequiter fecit per Blasium marangonum, de quo Blasio iam debita iusticia facta est, captum est per nos et nostra consilia minus et $\mathrm{XL}$ quod dictus Zaninus baniatur perpetuo de omnibus terris et locis subiectis nostro dominio, et quod quicumque ipsum dabit vivum in fortia dominii, habeat a nostro comuni ducatos IIII ${ }^{\mathrm{C}}$ auri. Quare committimis tibi quod dare debeas operam ad capi faciendum ipsum Zaninum in partibus tui regiminis et ipsum sub bona custodia in catenis ferreis mittas ad nos secundum iusticiam puniendum. (Cassum. In margine: quia mortuus expiravit).

[48] Item observabis partem captam in XL contra Alvisium Bedoloto, ut in commissione potestatis Iustinopolis sub signo $\mathrm{X}_{13}$. Ceterum scire debes quod propter enormes excessos commissos per Alvisium Bedoloto contra nostrum honorem, captum est per nos et nostra consilia minus et XL, 1357, 29 septembris, quod idem Aloysius perpetue banniatur de omnibus terris et locis subiectis comuni Veneciarum. Et si umquam venerit in fortiam nostram, amputetur sibi manus sinistra et ultra hoc finiat vitam suam in uno carcere inferiore. Et quod si venerit in aliquem nostrum locum, rector illius loci ipsum capi faciat et faciat amputari sibi dictam manum et ipsum postea mittat Venecias sub bona custodia. Et quicumque dederit ipsum in fortiam dominationis vel rectorum nostrorum, vel accusaverit eum ita quod veniat in fortiam nostram vel rectorum nostrorum, habeat a nostro comuni libras IIIC ${ }^{\mathrm{C}}$. Quare comittimus tibi quatenus predicta in quantum ad te spectant observare et observari facere debeas. ${ }^{205}$

\footnotetext{
$\overline{202}$ Le commissioni ducali, 95: au.

203 Le commissioni ducali, 95: fiat.

204 Le commissioni ducali, 96: istigatus.

${ }^{205}$ List iz registra na koji se upućuje je izgubljen. Tekst ove glave preuzet je iz izdanja Le commissioni ducali, 130, gdje je rekonstruiran uz pomoć prisege koparskog podestata iz sljedećeg sveska serije Formulari di commissioni.
} 


\section{Summary}

\section{Oaths and Instruction - Legal Framework for the Authority of Venetian Rector in Mediaeval Dubrovnik}

The paper analyses two oaths and an instruction, legal documents on which the authority of Venetian rector ruling mediaeval Dubrovnik rested. The text of rector's oath to the doge, so far not tackled in Croatian historiography, has been analysed in detail and published. The text is a rich source of information on Venetian rule in Dubrovnik in the 13th century and the first half of the 14th century. The paper tackles links among the subject documents, and their importance for the legal system in Dubrovnik. It further questions their connection to the then popular literature on good government.

Keywords: Dubrovnik; Venetian Republic; Middle Ages; rector; authority; oath; instruction. 
